\title{
The 2016 Josephine Waters Bennett Lecture: Humanism and Printing in the Work of Conrad Gessner
}

\section{Citation}

Blair, Ann. "The 2016 Josephine Waters Bennett Lecture: Humanism and Printing in the Work of Conrad Gessner." Renaissance Quarterly 70, no. 1 (2017): 1-43.

\section{Permanent link}

http://nrs.harvard.edu/urn-3:HUL.InstRepos:41376563

\section{Terms of Use}

This article was downloaded from Harvard University's DASH repository, and is made available under the terms and conditions applicable to Open Access Policy Articles, as set forth at http:// nrs.harvard.edu/urn-3:HUL.InstRepos:dash.current.terms-of-use\#OAP

\section{Share Your Story}

The Harvard community has made this article openly available.

Please share how this access benefits you. Submit a story.

\section{Accessibility}


Ann Blair, "Printing and Humanism in the Work of Conrad Gessner," Renaissance Quarterly, 70:1 (2017), pp. 1-43. Pdf of final author's manuscript for DASH, Harvard University.

\section{Humanism and Printing in the Work of Conrad Gessner}

ANN BLAIR, Harvard University

I discuss how printing affected the practice of scholarship by examining the working methods of Conrad Gessner (1516-65), a prolific humanist, bibliographer, and natural historian. Gessner supplemented his revenue as city physician in Zurich through his publishing activities. He hailed printing, along with libraries to preserve the books, as crucial to the successful transmission of learning to the distant future. Gessner also used printing as a kind of social media: to reach readers rapidly all over Europe, in order to solicit contributions to his research projects underway, to advertise forthcoming books, and to develop his own thinking through multiple iterations.

\section{INTRODUCTION}

Given the strong competition for anniversary attention in 2016 (including Shakespeare, Cervantes, and Erasmus's edition of the New Testament), Conrad Gessner no doubt seems a lesser light by comparison. ${ }^{1}$ His works are generally not available in translation or in print today, but thanks to the digitization projects of e-rara and the Bayerische Staatsbibliothek almost all of his sixteenthcentury imprints are now readily accessible. ${ }^{2}$ My argument for Gessner's significance is that he offers us a valuable window into the motivations and working methods of a late humanist scholar, because they are uniquely visible in Gessner's case thanks to his volubility about them, on the one hand, and to the scale of his publishing activity, on the other.

Gessner is best known today for his massive illustrated natural histories and his pioneering works of universal bibliography and associated topical index. But these most famous of his works represent only a fraction of his total output. Gessner applied his skills in gathering, assessing, and organizing information to a wide range of other topics, such as milk and cheese making, the diversity of languages, the baths of Switzerland, and the gardens of Germany. In just twenty-five years Gessner published a steady stream of Latin books, in which he described his role variously as translator, compiler, editor, or author. He published at an average rate of more than two books per year, with seven books appearing in his annus mirabilis in 1555 (fig. 1). ${ }^{3}$ Not surprisingly, given his training and employment as city physician in Zurich, Gessner published many explicitly medical works, from collections of remedies or diagnoses to a handbook on surgery and advice on keeping good health. Less well known are Gessner's humanist activities, which extended beyond discussions of the ancient terms for animals, plants, and minerals in his natural histories, and bibliographies of ancient authors in his Bibliotheca. Gessner published at least eight editions of Greek texts, among them editiones principes for Aelian's natural history (1559) and the meditations of Marcus Aurelius. ${ }^{4}$ Gessner's edition of the latter, based on a manuscript in the library of Otto Heinrich of Palatine that was subsequently destroyed, has been crucial to all later editions.

Gessner also translated these and other Greek texts into Latin, often for the first time, including the sententiae of Stobaeus (1543), the Homeric allegories of Heraclides Ponticus (1544), or the Navigatio of Hanno of Carthage (1559). Finally, Gessner composed humanist commentaries on major authors like Aristotle and Galen, and minor ones like Xenocrates, a Platonist of the fourth century BCE (in 1559), or Epiphanius, a Greek church father of the fourth century CE (in 1565). ${ }^{5}$ Gessner also deployed Latin editorial skills in his expurgated edition of Martial (1544) and in publishing the manuscripts of five recently deceased scholars in seven different books. ${ }^{6}$ Many 


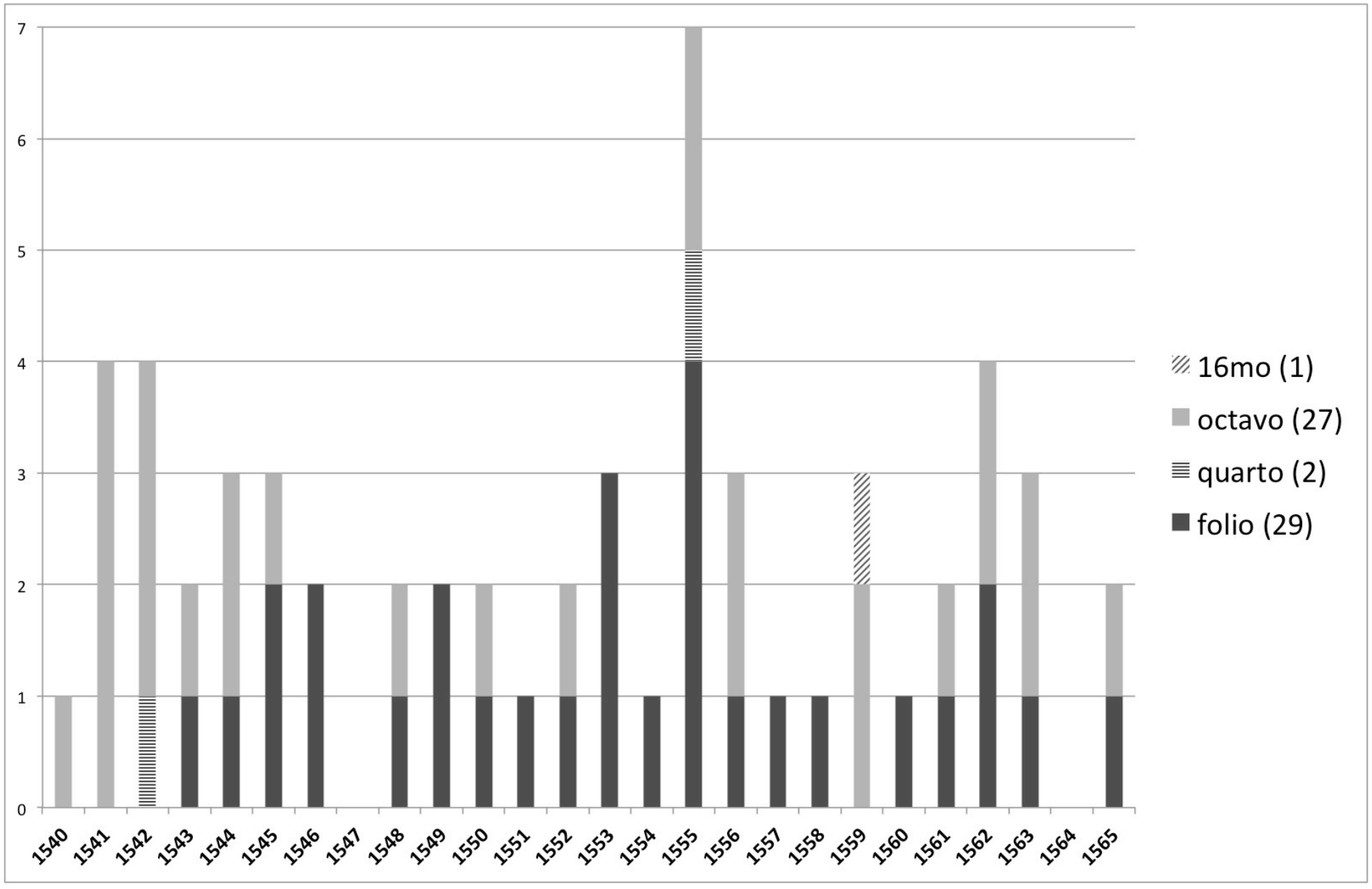

Figure 1. Graph of Gessner's publications by date and format. 
factors contributed to Gessner's remarkable productivity, including his wide range of interests and of scholarly contacts and an indefatigable capacity for work, but crucial among them was his clear sense of the benefits of printing.

The role of printing in early modern Europe has proved a topic of enduring study and debate, especially since Elizabeth Eisenstein's 1979 blockbuster The Printing Press as an Agent of Change. Eisenstein passed away in 2015, after more than forty-five years of membership in the RSA, leaving us with a body of synthetic work and incisive argument about the multiple impacts and uses of printing. ${ }^{7}$ In this essay I'll argue that Gessner viewed printing as a source of income, as a bulwark against loss - preserving ancient and new texts for the future - and as a working tool essential to his methods of research and writing. Explicitly, Gessner hailed printing as a means of transmitting texts into the indefinite future, like monuments made impervious to destruction. Tacitly, he used printing as a means of communication in the here and now, serving purposes we associate with today's social media-from profusely thanking those who contributed to his projects, to subtly shaming those who could have done more, and addressing unknown readers in the hope of eliciting new correspondents. Gessner also communicated with himself through printing, using his copies of his own publications as the basis for storing information, for planning revisions and new compositions. As a result his five dozen publications have both withstood the test of time and carried with them traces of Gessner's reliance on print as a tool for rapid impact in his day-including signs of and apologies for haste, digressive paratexts that stray from the theme of the book, and texts brought together in one volume opportunistically in combinations that strike us as haphazard and closer to the medieval miscellany than we might expect from a printed book.

\section{PUBLISHING AS A SOURCE OF INCOME FOR GESSNER}

By Gessner's time printing was well established, as were the conventions of the "modern book" (to use Henri-Jean Martin's parlance), including title page, pagination, and multiple paratexts, some of them specific to printed books, like lists of errata. ${ }^{8}$ The distribution of printing centers and of the book trade had also stabilized by this point after the rapid proliferation of printing cities followed by sharp consolidation at the end of the fifteenth century..$^{9}$ Gessner's Zurich was a minor printing center compared to nearby Basel, which was closer to distribution networks given its position on the Rhine and had the seventh-highest output among printing cities in sixteenth-century Europe. ${ }^{10}$ Gessner published more than half his books with two printers in Zurich: Christoph Froschauer, who published twenty-four of Gessner's books between 1541 and 1565, and his relatives Andreas and Jacob Gessner, who published fourteen of them between 1552 and 1565 . The remaining twenty-odd books of Gessner's appeared mostly in Basel, but also in Strasbourg, Lyon, Geneva, and Venice.

We have no systematic record of Gessner's or his printers' finances, but piecemeal evidence indicates that one motivation for Gessner's prolific publication was financial. Although Gessner was paid for his work as city physician and for teaching natural philosophy at the Carolinum in Zurich, he felt under constant financial pressure, as he complained in a letter he wrote in 1558 to Heinrich Bullinger, Zwingli's successor as religious and temporal leader of Zurich: "Frobenius (the bookseller) in Basel, demands that I compare for him the Latin translation of Galen's complete works with the Greek original text (a work that demands an immeasurable amount of labour), and I have to give him my decision within a month. Froschauer (the famous printer in Zurich) asks me to make for him an excerpt from my three large volumes of the natural history of animals. Exhausted from so many exertions, emaciated, enfeebled, half blind, ... shall [I] again take on a work that would not let me breathe freely for two or three full years. Would 
you, my friend, advise me to do this?"11 This emotional appeal indeed resulted in a raise from the city and Gessner declined both these printers' solicitations, which suggests that he would have taken them on only for the income they would have provided.

In fact, Gessner ended up contributing to Froben's complete works of Galen mentioned in his letter to Bullinger, but at a higher level than what Froben had initially requested: whereas someone else was paid fifteen pounds to collate the translation as Gessner had originally been asked to do, Gessner was paid a total of thirty pounds for providing the preface to the edition. ${ }^{12}$ This was a tidy sum, which corresponded to more than a month of his pay from the city (before the raise). But this was also no ordinary preface: at seventy-three folio pages it was a significant piece of scholarship including a complete bibliography of Galen's works. ${ }^{13}$ In dedicating that work to Basil Amerbach and the faculty of the University of Basel, Gessner offered an oblique acknowledgment of what he owed the printers: "Since it pleased the printers, from whom I am conscious of many great benefits toward me, that I should write the preface, I could not dare refuse them, however much I was aware of my weakness." ${ }^{14}$ In addition Gessner could also receive payment from dedicatees. In fact, we know that Gessner received five taler (worth two gulden each) from the senate of the University of Basel to whom he dedicated this particular work. ${ }^{15} \mathrm{We}$ know about these payments in part because collective bodies like city councils and university senates made and preserved records better than individual authors or dedicatees. But I will also argue below that many of Gessner's individual dedicatees likely made contributions in kind to Gessner's projects rather than in monetary form.

We must not infer from Gessner's letter that he was actually indigent. Urs Leu has recently concluded that Gessner earned 142 gulden per year from the city of Zurich, including a monetary value placed on the annual allotment of wine and grain awarded by the city council in response to his dedication to them of the first volume of his Historia animalium in $1551 .{ }^{16} \mathrm{He}$ could earn additional sums from private medical practice and agreements with publishers. But Gessner's commitment to research on so many fronts clearly also incurred considerable ongoing expensesto pay for books, writing supplies, and mail services, and to maintain in good condition his growing collection of research materials, which ranged from papers to dried and living plants and even a few animals. In 1558 Gessner added a third floor to his house, complete with fifteen windows to accommodate his collection and his working space-perhaps this exceptional expense motivated him to write to Bullinger. ${ }^{17}$ In his letter Gessner also invoked the needs of his large and poor family, mentioning his mother and many nieces and nephews since Gessner and his wife had no children. Similarly, two years later Gessner explained that he was "very poor" and had "forty needy relatives" when he appealed to Elizabeth I to recoup the expenses he incurred in sending her his Icones animalium after she took offense at his dedication. ${ }^{18}$ Although that claim of poverty may have been mostly a ploy by 1560 (and a successful one), Gessner likely felt under financial pressure for most of his life, due to his income being insufficient to his expenses and the expectations of his relatives.

Printers who paid him to edit, translate, compile, and compose offered a valued source of additional revenue. In 1559 Gessner wrote to a friend with relief that he no longer felt as subject to the pressures of printers. ${ }^{19}$ In fact, Gessner continued to publish at the same prolific rate and interestingly devised a distinctive prefatory trope in a number of his late publications, in which he explained that he was responding to a request from his relatives Andreas and Jakob Gessner to give them something to print. While he had not explicitly invoked financial straits as a justification for publishing, once he was financially more comfortable Gessner emphasized the role of family obligations in motivating his activity. Presumably, he sought in doing so to deflect criticism, 
whether because publishing so much seemed immodest or because it conflicted with Gessner's earlier appeal for increased support to free him from publishing.

The complexities of Gessner's relations with his printers are well worth further exploration, but my first point is simply that both Gessner and his printers expected to and likely did make money from his publications. ${ }^{20}$ Of course the particular forms of Gessner's relentless publishing resulted from an intellectual agenda: to rescue and transmit texts that had been or were at risk of being lost, and to advance multiple information-gathering projects in the here and now. Different features of printing were crucial to each of these goals.

\section{PRINTING FOR PRESERVATION}

Printing was no prerequisite for either the ideal or the reality of long-term preservation of text. The metaphor of text as a monument to withstand time dates back far before printing, to an era of oral publication and of writing on papyrus rolls that rarely lasted more than two or three hundred years, when Horace ended his Odes with this: "I have finished a monument more lasting than bronze, more lofty than the regal structure of the pyramids. . . I shall not wholly die and a large part of me will elude the Goddess of Death. I shall continue to grow, fresh with the praise of posterity."21

It is hard not to be impressed with the accuracy of Horace's prediction. The poor durability of the medium of his day proved of no consequence given the strength of the cultural survival of the text, thanks to its place in a long-lasting canon that ensured copying onto new media as needed - fresh papyrus rolls, parchment codices, printed books, and now electronic formats. ${ }^{22}$ By contrast, Mayan petroglyphs, for example, have proved durable materially but not culturally; the knowledge required to read them was not transmitted, so scholars struggle to decipher them. Effective preservation requires material longevity if there are significant gaps in the cultural durability of the text. And even if Horace accurately forecast his transmission, I suspect that we are poor judges of the cultural or the material longevity of our own productions.

Preservation was a problem that preoccupied Renaissance humanists greatly, given their focus on recovering ancient learning. It is supremely difficult to estimate the extent of the loss of ancient learning because many authors and works are no doubt completely consigned to oblivion, but we know some of what is missing thanks to references and excerpts that have come down to us from authors whose works were not transmitted. On that basis one scholar has recently estimated that less than 4 percent of the ancient plays that once existed have survived. ${ }^{23}$ What percentage of ancient writings Renaissance humanists thought had been lost is the more historically interesting question. Aaron Shapiro, who recently finished a dissertation on this topic, points out that in an oration of 1494 Pietro Bembo estimated the survival rate of Greek manuscripts at one in one hundred. ${ }^{24}$ This dire estimate motivated humanists to cry "never again": for any ancient text they could rescue from near oblivion and for their own compositions, a top priority was to ensure safe and durable transmission to posterity. Elegant copies on parchment were certainly expected to achieve this goal and they did, but printing offered further protection through the production of large numbers of copies. Moveable type (which required printers to decide in advance how many copies to print) and the commercial motives of printers ensured that books were each printed in hundreds of copies; a print run of 1,000 copies is considered a reasonable estimate for learned books in the late sixteenth century. ${ }^{25}$ Humanist efforts to recover, edit, and transmit lost ancient texts had been underway for more than a century before the invention of printing, but humanist texts were also among the first to be printed, as early as the late $1460 \mathrm{~s}$, with the publication of Cicero and then other classical texts by Sweynheym and Pannartz in Subiaco and then Rome. Of course printers would only undertake these editions if they perceived sufficient cultural demand, 
and they could easily miscalculate, as the rapid demise of Sweynheym and Pannartz's printing business illustrates. ${ }^{26}$

Gessner felt the trauma of the loss of ancient learning especially keenly. The desire to aid in the recovery of lost texts and the preservation of found ones was the main reason that Gessner adduced for taking on at age twenty-six a novel and arduous task, to compose a "universal library or most abundant catalogue of all writers in the three languages of Latin, Greek and Hebrew, extant and not, ancient and recent, learned and not, published and hiding in libraries. ${ }^{, 27}$ When he was done three years later-after composing a text of 1,300 folio pages listing 10,000 works by 3,000 authors - he compared the experience to having climbed the tallest steep mountain. ${ }^{28}$ The work begins with Gessner's mourning the terrible record of destruction of books and libraries, from antiquity to his own time: "Where are now the 700,000 volumes of the library of Ptolemy Philadelphus or the 3,000 volumes of Tyrannion [a Greek grammarian]? Aulus Gellius describes that 70,000 volumes of Alexandria were burned by soldiers." ${ }^{29}$ Gessner goes on for two pages in this vein, ending with the sack of Buda, which occurred "in the memory of our fathers" and destroyed the great library formed there by Matthias Corvinus. Then Gessner exclaims: "But what now remains of all these glorious libraries except an empty reputation? ... So many and such precious books in every philosophy were gradually lost, some consumed by flames or the tumult of war, some by age itself corrupted by worms or an unhealthy location, many dissipated by negligence and the hatred of barbarians for learning." ${ }^{.30}$ What could be done? Gessner explained his solution: "I have opened a way and given a great occasion to others, by which the wealthy and the princes can establish libraries, which are necessary for transmitting books to posterity." 31

In his alphabetical listing of authors Gessner included not only those whose works were well known and already printed (which he did diligently, often including tables of contents and excerpts from prefaces), but also those whose works had not yet been found. To include the names of ancient authors of which little or nothing survived Gessner explained that he trawled through doxographically rich works like Athenaeus, Stobaeus, or the Byzantine Suda dictionary, and, "I regularly noted with excessively exquisite or curious diligence any names that occurred while reading them: . . . even those from whom nothing published survives, or only some prefaces, or even just one, or a single letter." 32 As a late humanist seeking to make a contribution after the major ancient texts were already available in print, Gessner was especially alert to the value of bare names and fragments that had not yet been published. ${ }^{33}$ In his correspondence Gessner was on the lookout for new texts to publish and he aided substantially the knowledge of fragments by publishing in Greek and Latin the sententiae of Stobaeus from the fifth century and a collection of theological sententiae by two Greek monks of the seventh and eleventh centuries, Maximus and Antonius of Melissa. ${ }^{34}$ With the Bibliotheca as a guide, scholars would know what lost works to look for and the princes on whom Gessner called to build great libraries would know what works they were missing in order to commission and buy them.

Like many contemporaries, Gessner considered printing a providential gift in this worthy enterprise of rescuing and transmitting texts: "Today the art of typography, granted by God to the men of our time for the preservation of letters to posterity, will supply authors of every kind. By this art as much is produced in one day by one man even unskilled in letters, as it was barely possible to produce in a whole year by several men with the speediest quill." ${ }^{35}$ But Gessner also noted that printing posed a new kind of risk of oblivion - due to good (i.e., ancient) works becoming lost in a sea of new ones of little worth: "Although the typographical art seems to have been born for the conservation of books, most of the time nonetheless the silliness and 
useless writings of the men of our time are edited, to the neglect of the old and better ones." 36 For this problem too a well-funded library was the solution, including libraries devoted to manuscript books alone, which Gessner advocated. Gessner was not unusual in these observations, echoing Erasmus, among others, ${ }^{37}$ but he directed them to someone he thought could act on them: his dedicatee, the imperial counselor Leonard Beck von Beckenstein. Gessner praised Beck von Beckenstein's library and clearly hoped to inspire him to further patronize scholarship, but beyond Gessner's multiple addresses to him in 1545, 1548, and 1555, we know little about his interest in learned books. ${ }^{38}$

Gessner viewed the combination of printing and libraries as the key to transmission to posterity not only of recovered ancient texts, but also of his own books. In dedicating his edition and translation of Aelian's natural history to Johann Jakob Fugger in 1556, Gessner thanked him for the loan of Fugger's very old Greek manuscript that he had used and expressed the hope that Fugger would add to his library Gessner's new edition: "Welcome easily and benevolently the return of your Aelian, now complete, corrected, bilingual, and published, and admit it into your library as if by the law of hospitality." 39 Gessner addressed a similar injunction to the city council of Augsburg to whom he dedicated his edition of Dioscorides in 1565. On that occasion too he had worked from a manuscript from Augsburg, but a recent manuscript left unfinished at the death of the scholar Joannes Moibanus. In his dedication Gessner explained that during his fatal illness Moibanus sent his edition of Dioscorides's De curationibus morborum to Gessner to finish and publish, requesting that he dedicate it to the city of Augsburg on behalf of his three orphaned children. Gessner did his part and even delayed other projects to carry out this one, which he indeed dedicated to the city council on behalf of the Moibanus orphans, but he also put in it a good word for his book: "Please add this volume to your library, that ornament to your city which was begun by you and which will grow in perpetuity." ${ }^{40}$ Gessner had high hopes for the preservation of both his own work and the manuscripts that he published through the combination of printing and well-maintained libraries.

Of course there have been losses of early printed texts, especially of unbound printed matter and ephemera, but by and large Gessner's hopes for the improved preservation of books through printing and early modern libraries have been borne out. ${ }^{41} \mathrm{We}$ have not in the intervening 500 years experienced a loss of learning of the kind that had traumatized Gessner and generations of humanists. Gessner's works themselves are preserved, though not all in one library, from the lavishly illustrated expensive folios, to the cheaper, smaller, functional books that never became collectibles. The redundancy and wide geographical diffusion made possible by printing were central to their survival, as Gessner understood. One of Gessner's motives in publishing was to transmit for the long term works of others, ancient and contemporary, and his own.

\section{PRINTING IN GESSNER'S WORKING METHODS Publicizing Thanks}

In addition to carrying texts far into the future, printing and the book trade also carried them rapidly throughout Europe at the time. Gessner used printing both to encourage his readers to contribute to his projects, and to develop his own works through successive printed iterations. Gessner's principal modus operandi was to accumulate material over many years that fueled the steady stream of his publications. Gessner himself traveled only occasionally beyond the Swiss cantons, e.g., to Lyon, Paris, Montpellier, Strasbourg, Augsburg, and Venice. Instead, working from Zurich, Gessner gathered information from correspondents and visitors from all over Europe. ${ }^{42}$ His correspondence survives only in part thanks to two volumes published soon after his death and various extant 
manuscripts. ${ }^{43}$ I have focused on his publications, and especially his paratexts, as a trove of evidence about how he received and elicited materials for his many projects - manuscripts for editions, bibliographical references for the Bibliotheca and its sequels, images, specimens, and observations about animals and plants for multiple volumes on natural history, but also medical remedies or samples of foreign languages. ${ }^{44}$

For example, Gessner's Mithridates, named after the king in second-century Anatolia who inured himself to poison by taking small doses but who also reportedly spoke the twenty-two languages of all the areas he controlled, was dedicated to John Bale who lived in Zurich at the time as a Marian exile. Gessner thanked Bale for his contributions to the Bibliotheca of ten years prior and for contributing to this new book, in particular a specimen of Old English. Then Gessner requested further input: feedback about things to change or correct in this book, and more specimens (especially the Lord's Prayer) from other languages of Britain, e.g., from Ireland or the Isle of Man. ${ }^{45}$ But what use would these contributions be since he had just published his book on the topic? Gessner addressed that concern explicitly in a closing epilogue: "I have dared to write about all languages, not really because I hoped to do justice to the inquiry ... but in order to excite others to write, either by their own reflections on one or more [languages], which I would prefer, or to write to me in order to augment or emend this work some day." ${ }^{46}$ So Gessner envisioned himself continuing to gather material on the topic, and perhaps he actually received some input, although he did not in fact publish about the diversity of languages again.

We can catch a rare glimpse of how Gessner accumulated material from three volumes prepared for publication after his death but left in manuscript at the Zentralbibliothek: the "Thesaurus practicae medicinae," gathering medical remedies appropriate for various diseases. The folio pages ready to be printed consist of a collection of remedies organized by disease. The remedies were written on slips, some of them copied in Gessner's hand, others cut out from letters Gessner had received, or from printed material. Before this final compilation, the slips would likely have been stored loose, in bags, pigeonholes, or an equivalent sorting device, to which new material could be added as it arrived. Gessner thus explained to a correspondent who asked him to refer back to an earlier letter that he could not since he had already cut the letter up. ${ }^{47}$ Who knows what that correspondent thought, but we can understand that Gessner was distributing the information so he could use it later. Gessner's hallmark method was to gather together material from all kinds of sources: books already in print, manuscripts never printed before, his own observations, letters from correspondents far and near, people he knew well, and scholars whom he never met in person. And printing proved a crucial tool for soliciting new input. Gessner used his frequent publications to thank those who had contributed to his projects and to invite others to follow suit.

Paratexts proliferated in sixteenth-century books - printing may have favored the multiplication of paratexts in a variety of ways - but acknowledgments were not among them. Acknowledgments motivated by a desire to record intellectual debts appeared in the late nineteenth century with the professionalization of academic fields, as nicely studied by Françoise Waquet. ${ }^{48}$ Nonetheless, Gessner said a lot of thank-yous, sometimes in the body of his texts, but especially in his paratexts - in dedications, but also in addresses "to the reader" and in the unique "catalogue of learned men who helped," which Gessner introduced at the front of three volumes of his Historia animalium.

Dedications are not unique to printed books. Ancient and medieval authors from Pliny to Dante composed dedications to rulers and patrons that typically circulated beyond the dedicatee when the manuscript was copied. But printed dedications reached a broader public, and printing added to the impact of receiving a dedication and explicit thanks within it. ${ }^{49}$ Occasionally, Gessner alluded to 
the lasting honor associated with print. After forecasting long-lived glory to his dedicatee given his virtues, Gessner explained: "For that reason I wanted to dedicate the writing of some learned man to you, which would be of the sort that, so it seems, would last forever; which I must not and cannot hope for my own works." ${ }^{50}$ Gessner made explicit how the reputations of noble dedicatee (Beck von Beckenstein), the deceased learned author (Antonius Thylesius), and the learned editor (Gessner) were all bound together through the printed dedication, aiming to extend their reputation into the future. Of course Gessner did so by declaring that the glory of the dedicatee redounded to the deceased author, but was not the subtext here that Gessner was the true source of their bid for immortality by putting them both into print? In dedicating his Onomasticon (dictionary of proper names) to a group of nine young Zurich patricians and former students of his, as a New Year's gift in 1549, Gessner observed with less convolution, "I thought you would enjoy the dedication of this book to your names." 51

Gessner's thanking of course showed off the range of his personal contacts and enhanced the authority of his work as a result. But it also offered the promise to anyone who would contribute material to Gessner that they could appear and be thanked in print too. To Joannes Echtius, a doctor in Cologne, Gessner began his dedication: "I finally received the images of fish of the German ocean you gave me which I had been longing for: for which I wanted to thank you not by words alone but by showing you some tangible example of my gratitude." 52 To Johannes Pontisella, rector of the Latin school in Chur, Gessner wrote recalling his help on the topic of plants, inviting him to send more observations from the mountains of the Grisons, then requesting that he greet mutual friends there-the ministers Ioannes Fabricius and Philippus Gallicius and the doctors Zacharias Belinus and Hieronymus Brixinus. ${ }^{53}$ Gessner's dedication to John Parkhurst, bishop of Norwich, similarly mentioned Gessner's multiple English contacts - many of them Marian exiles recently returned to England at the accession of Elizabeth I - and Gessner cross-thanked especially John Caius, "from whom I received very many images of birds and other animals, along with descriptions accurately and carefully written by him." 54 With thanks came explicit requests, designed to keep stimulating the cycle of contributions and thanks. Of Parkhurst, Gessner went on to ask: "If you could use your authority so that some learned men among you would send me images of those birds which are found in England beyond those which I have shown here, I will be sure to augment this book with those images and perhaps others (if I receive some from elsewhere in the meantime), God willing." 55 Gessner spells out here how his appeal for new images would result in publication: he promised to include images sent in after this volume in the next volume. Indeed, in his many successive treatments of natural history Gessner regularly included sections entitled paralipomena or addenda. Gessner included there images received after the rest of the volume had been completed as a supplement to that volume or to an earlier one in the series.

\section{Serial Printing}

Gessner started his Historia animalium in 1551 with a volume on viviparous quadrupeds - a monumental book of 1,160 folio pages. The book comprised so many paratexts that Gessner included a unique table "of the things are treated before the entry into the work," listing the paratexts in order of appearance. ${ }^{56}$ The volume looks like the achievement of a lifetime, carefully brought to completion. But it was in fact only the start of a long sequence. In 1553 Gessner offered a new iteration on the topic, the Icones animalium, focused on images of viviparous and oviparous quadrupeds, with minimal learned discussion - this kind of picture-book version in the same format was a way to maximize revenue from the costly images by reaching a different audience than the original massive volumes in which the images were outweighed by Latin text. ${ }^{57}$ But the Icones were also the opportunity for Gessner to add an appendix of ten pages of quadrupeds not listed in 1551 (fig. 2): 


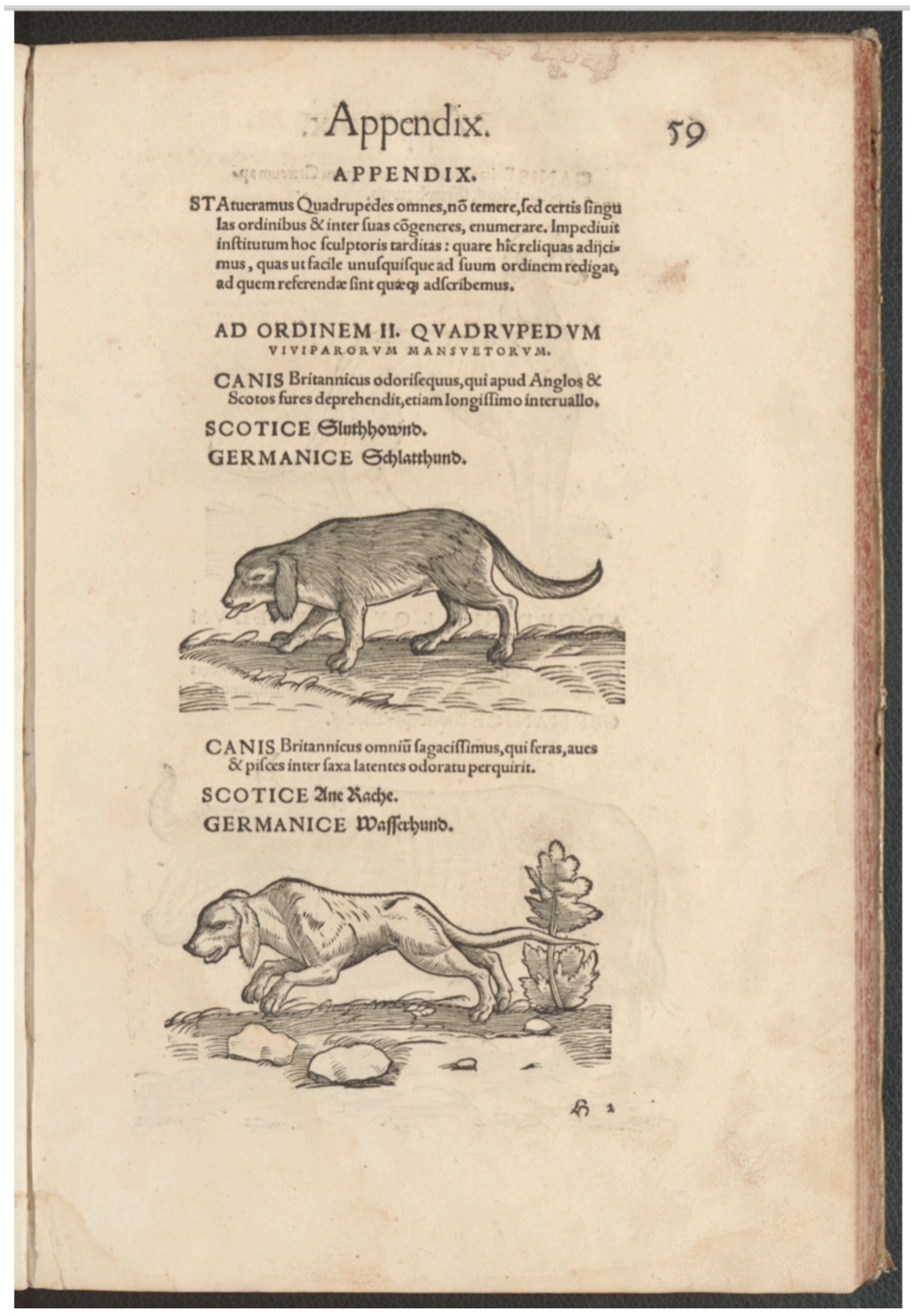

Figure 2. Icones animalium (1553), appendix, page 59, featuring images delayed by the carver. Reproduced with permission from the Zentralbibliothek Zürich, shelfmark AW 1. 
"We decided to list quadrupeds according to certain orders. But the delay of the carver prevented this plan, therefore we have added these images here which each reader will be able to bring to its proper order easily." "58 The first entries in the appendix are English dogs (sleuthhound, ratch, and greyhound), based no doubt on information from John Caius who later published a book on the topic. ${ }^{59}$ But even this appendix was incomplete: at the end of it Gessner apologized in a brief "to the reader" that he had received some images for which woodcuts could not be carved in time (e.g., for the Scottish white bison), and promised to print them in an upcoming volume (fig. 3). Along with that promise he appealed to readers to send him new images too: "Perhaps friends or others unknown to me but who are men studious of natural things will send other images as well which they notice we are lacking. We will add those separately at the first convenient opportunity so that they can be joined to these; and the same is true for other images about other kinds of animals." ${ }^{60}$ Indeed, the following year Gessner published the second volume of the Historia animalium, on reptiles. After 125 pages on reptiles Gessner offered a twenty-five-page appendix devoted to quadrupeds, including some of the images he had apologized for not including in 1553, like the Scottish white bison, as well as several others (fig. 4). ${ }^{61}$ As a result, one-sixth of the book on reptiles actually concerned viviparous quadrupeds. But Gessner's system of soliciting new contributions in each book worked because he could be counted on to have another work in press before long in which these could be included, regardless of the topic.

In 1555 Gessner published the third volume of his natural history, on birds. In the front matter to this volume Gessner cast his widest appeal yet, after the catalogue of learned men who helped, addressing all readers in a general plea for contributions, but targeting especially those in far-flung locations like Spain and the remote regions of Scandinavia from which he had little material (fig. 5): "I ask that all learned men in remote regions who might come across these books, first to be fair and benevolent judges, then if they have something to correct or add with new descriptions or images or to illustrate in some other way, that they do so honestly and generously and rapidly."62 Gessner assured readers that, even if they could contribute even just one thing, it would be most welcome. Gessner explained how readers wishing to send him something should find a merchant in their hometown who frequented the fairs of Antwerp, Venice, Lyon, or Frankfurt; there, their merchant could pass on to a merchant from Zurich material to reach Gessner. Gessner promised to answer by the same route in reverse "to the learned and generous men who will tell me their name and to whom I can express my gratitude in writing or by sending them something they would desire." ${ }^{23}$ Gessner thus offered to fill a request in return, in case getting thanked in print was not reward enough.

But the following year Gessner was still dissatisfied with his sources for Northern Europe, so he tried a cold-call dedication. His De piscibus of 1556 included four dedications, one for each of its four parts since the main text is followed by three additional ones (fig. 6). Most were dedications of the common type ("thanks for what you sent and please send more") but in the section on German and English names of fish Gessner addressed his dedication to someone he did not know-Burchard Mythobios, "most noble physician and philosopher . . . in a remote part of Northern Germany" (fig. 7). ${ }^{64}$ Gessner started by dropping the name of a mutual acquaintance: "Thomas Erastus, my countryman, in writing to me recently praised spendidly both your erudition and your humanity." Then he got to the point: "Erastus added that you had some rare images of animals, especially fish from the Baltic sea, which you promised to communicate to me if some opportunity arose to send them across such a large distance. ... I chose you above all as the best patron of this work and the most learned judge of it ... also so that you would deem me worthy to share with me as many images, painted or drawn that you have, especially of fish." And Gessner closed with a little more flattery: "I 


\section{Ad Lectorem.}

S VPERSVNT nobis adhuc Quadrupedum generis icones quadam, ut Mufi. mononis é Sardinia, Simix Tartarinæ quæ cynocephalorum generis uidetur, Bifonis feu bouis ferialbi Scotici,Ranx rubeta, \& T eftudinis terreftris, qux hoc tempore à fculpto re perfici non potuerunt. Mittent $\&$ amici quidam fortafsis aut etiam ignoti nobis, fed re rum naturæe ftudiofi homines, etiã alias effigies quas nobis deeffe animaduerterint. Eas quoç nos prima quaq̧ commoditate feparatim ædemus ut hifce adiungi pofsint $:$ ut $\&$ rèliquas de cæeteris animantium generibus figuras. Ipfius quidem Hiftorix $\&$ defcriptio $=$ nis animalium reliquorum poft Quadrupedes Volumen Latinum iam fub prælo eft: \& Tomus primus de Quadrupedibus in Germanicum fermonem translatus : quietiam Gallicé propediem excudetur. Quòd ad ipfas figuras non eft quòd hîc quicquam ex= cufemus, cum id in Prefatione primi de animalibus Tomi, iam preetiterimus. Omnes fanè ad uiuũ depiêtę funt, preter paucifsimas, in quibus quod res erat monuimus, Vale。

\section{N D X L A T IN VS.}

\begin{tabular}{|c|c|c|c|}
\hline AFRICANA $3^{2}$ & Crocodilus & Lepus & Pardus. \\
\hline 27 & Crocodilus terreftris & Lupus & ceros, \\
\hline 35 & & pus ceruarius & 44 \\
\hline retomys & Cuniculus $\quad 47$ & 39 & Raingus \\
\hline Irctopithecus & Uuniculus Indicus 63 & utrx fpecies Ichneu= & \\
\hline Irmelinus uel Armil & Dama recẽtiorum & mon & Ranæ fotus caudatus \\
\hline 64 & 25 & Lynx & \\
\hline dinus & romas & Lyndis alia effigies 32 & au \\
\hline Belbus & Echinus & Mar= & , \\
\hline ifon & lephas & urellus & $\mathrm{R}$ \\
\hline Sonafus $\cdots$ & Emptra & pecies & iridis 5 \\
\hline 5 & 14 & 46 & $\mathrm{R}$ \\
\hline ruี 8 & rinaceus $\quad 48$ & 39 & \\
\hline suel & Faginus,uulgò Foi & IVlonoce & \\
\hline 28 & 45 & 16 & \\
\hline ica 18 & elis & Mus agr & ofa \\
\hline Is dro & Lyncẽ & non & \\
\hline & 31 & & \\
\hline 17 & 33 & 50 & \\
\hline 28 & uro uel Furus $\quad 44$ & Mus ca & Satyri \\
\hline 15 & Genetha uel Ge= & aưl & 2 \\
\hline$f u=$ & & uati $=$ & trũ \\
\hline 9. & 58 & +9 & \\
\hline & 33 & Mus d & \\
\hline$i=$ & $5^{2}$ & & \\
\hline & Gulo & 41 & \\
\hline 60 & yrinus & 41 & $\mathrm{~S}$ \\
\hline 10 & Hericius & uel Ve & \\
\hline 12 & If & is 50 & \\
\hline eolus & Hyæna $\quad 3 \mathrm{I}$ & 45 & \\
\hline & fpecies uide $=$ & 46 & \\
\hline hi Gi & 31 & fpes & \\
\hline 23 & Hy & 44 & \\
\hline 37 & 23 & ies & Is \\
\hline 19) & 41 & & \\
\hline 33 & $\mathrm{ma}$ & 50 & $\pi$ \\
\hline 41 & 41 & & $\mathrm{~T}$ \\
\hline us & Inftrumenta & Oui & \\
\hline 1 & & ge & \\
\hline 21 & cus 57 & bufdã & \\
\hline נו & 57 & ethizz & $\mathrm{Tel}$ \\
\hline $3^{2}$ & 36 & 64 & \\
\hline 22 & & & quio \\
\hline
\end{tabular}




\section{4}

\section{Appendix}

m frium hiftoria, (ubi etiam oftendi feriptores aliquot urum, bifonem, bubalư $8 \mathrm{x}$ benafum, confundere:) \& de uro, eodem libro pagina 157. \& rurfus in Paralipomenis pagina 1097. ubi bou $\widetilde{e}$ con bifone ex Sigifmundi Liberi fententia pietum, pro uro copiofius defcripfi. Miferat enim il hic probione ex Sigi un etiam lum tum temporis ad me doctiffimus felicis memorię uir Sebaftianus Munfterus proter ipfe acceperat, quoniam fic uulgò uocatur. Quodfi quis utrung; ex hifce bubus Latine urum pellârir, minoris rantum $\&$ maioris, aut barbati iubatiue differentia adiecta, reçe illum faciurum arbitror, quoniam bifonis aliud Latinum nomen non habemus.

B I S ON. Germanice Wifent. De quo ea tantum cognouip $n$ mus, qux iam inter cætera de Vro fcripta funt,

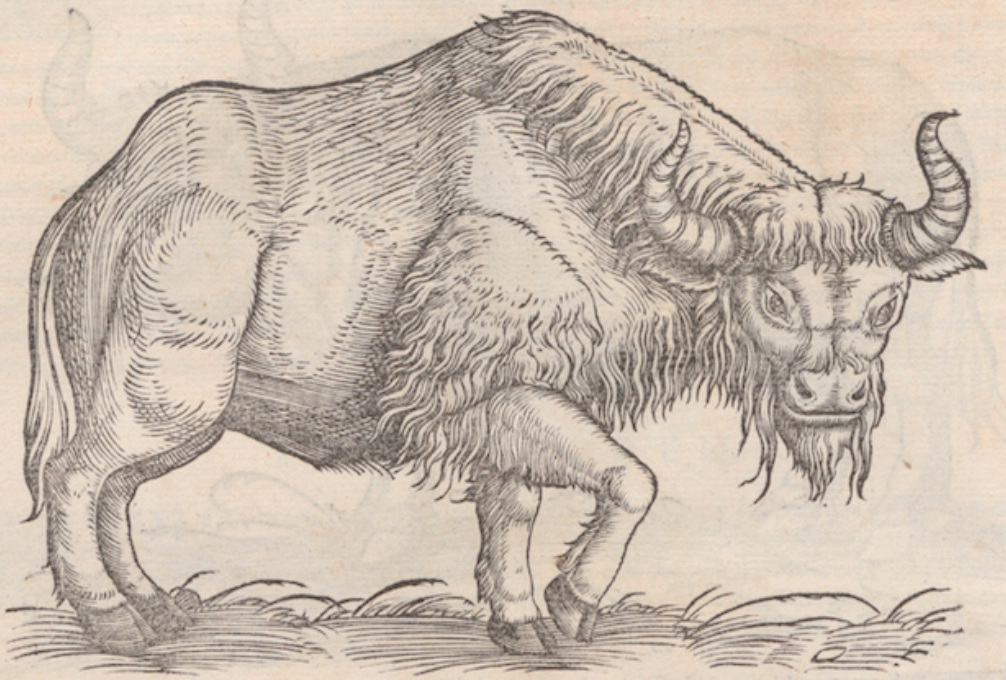

DE BISONE ALBO SCOTICO.

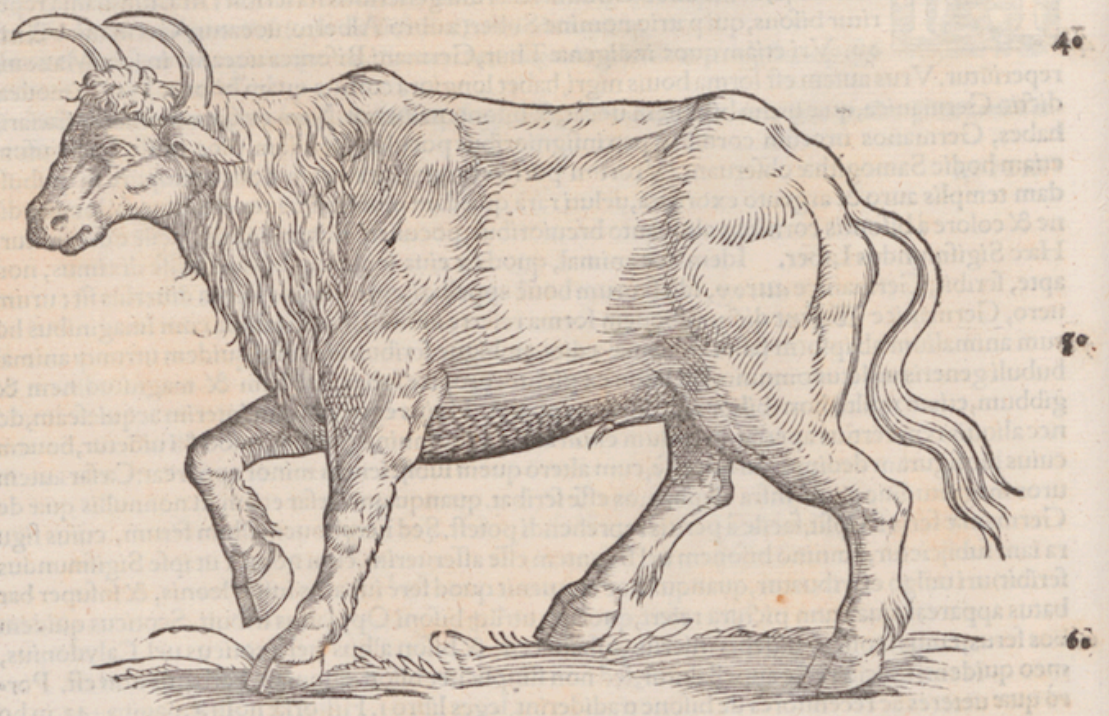

Figure 4. Historia animalium II (1554), appendix, page 4, featuring the white Scottish bison, which Gessner apologized for omitting in 1553. Reproduced with permission from the Zentralbibliothek Zürich, shelfmark 5.2. 


\section{AdLectorem.}

alterius innominati de accipitribus eorumḉ cura libros fimiliter Gracèfcriptos: ítem Äeliani aní maliẽ hiftoriam Græcam, quæ tamen interprete Petro Gillio iandudum Latiné legitur. Edoardus Publicati quah Vuortonus Anglus nuper de animaliũ differentijs libros decê æedidit, in quibus etiamfí fuarũ oba danı feruationum quod ad hiftoriam nihil adferat, neç noui aliquid doceat, laude tamen $\delta<$ lectione di* gnus eft, quod pleraq̧ ueterum de animalibus fcripta ita digefferit, ac inter fe conciliârit, ut ab uno ferè authore profecta uideantur omnia, ftylo fatis æquabili \& $<$ puro, fcholijs etiam ac emendationibus urilifsimis adiectis: $\mathbb{Q}$ quod priufquam ad explicandas fingulorum naturas accederet, quę com munia $\&<$ in genere dici poterät doctifsimè expofuerit. Petri Bellonij Cenomani de auibus librum Lutetix hoc ipfo tempore excudi audio, qui fortè iam abfolutus eft, ad nos quidem nỏndum perue nit.In illo non dubito raras aliquot auium \& icones $\&$ defcriptiones haberi. Nã ille partim in Gals lia, partim in remotifsimis orbis regionibus, quas peregrinationibus fuis ei inuifere datum eft, non pauca quibus nos caremus fibi comparare potuit. Idem in libro Gallico,quem Singulares obferua tiones infcripfit, paffim aliquot auium meminit, unde nos \& alia quædam $\&$ meropis effigiem mus ruati fumus.

\section{CATALOGVS DOCTORVM VIRORVM, QVI}

A D A B $S O L V E N D A M$ A VIVM HISTORIAM liberaliffìmè nos adiuuerunt,

Aegidius Tfchuđus Claronenfis, uir il= Ioannes Caius Anglus medicus. luftris.

Guliel,Rondeletius, medicus, in Schola Monfpelienfi profeffor regius, cuius nuper doctiffimi abfolutiffimióp de pi= fcibus libri prodiuerunt.

Hieronymus Zanchus Italus, theologix \& philofophię interpres in Schola Ar gentinenfi.

Hierony.Maffarius Vicẽtinus medicus.

Melchior Guilãdinus Boruffus mediç.

Ioannes Dryander, medicus $\&$ profeffor in $\AA$ ca demia Marpurgenfi.

Leodigarius Grimault Normannus.

Ludouicus Lauaterus Tigurinus, Ecclefiæ mia nifter.

Nicolaus Dalonuille dicecefis Charnoteñ.

Raphael Seilerus Auguftanus CL. v. Geryo nis Seilerimedici F.

Thomas Eraftus Heluetius medicus.

Vlyfies Aldrouandus Bononienfis medicus.

-Et præter hos alij in primo $\&$ fecundo libro à me nominati, tum ab initio librorum, tum etiam cum iconibus, defcriptionibus uel hiftorijs quas finguli communicarunt, ex diuerfis Germanix, Gallix, Anglix \& Italix regionibus ad me miffis. Scio etiam in Hifpanijs, in Dania \& remotiori= bus ad Septentrionem Scandinauix locis, multos effe doctiffimos uiros ad quos fortafsis noftri quoc; libri deportantur : quorum fi quis liberalitate ac beneuolentia fua me profequi, ac laboribus noftris fauere dignabitur: nx ille $\&$ mihi alacritatem $\&$ ftimulũ ad reliquos de aquatilibus, ferpenti bus $\&$ infectis libros citius abfoluendos addiderit, \& publicum in promouenda hac natura hiftoria beneficium praftiterit. Rogo itaç doctos omnes in remotifsimis regionibus, qui in hos libros in* ciderint, primum ut æquos ac benignos cenfores fe nobis exhibeant, deinde fi quid ad eos emen: dandos, augendos, iconibus $\&$ defcriptionibus nouis, aut quoquo modo illuftrandos conferre pof funt, id candide, liberaliter matureḉ ut faciant. Quod fi quis non multa docere aut communicare poffit, illum utcunq̧ pauca, \& uel unum aut alterum quippiam duntaxat nobis praffitiffe, gratiffis mum fưrit. Scribendi quidem mittendić; occafio nô deetit, per mercatores præcipuè, qui magna emporia frequentant, Antuerpiam, Venetias, Lugdunum, Francfordiam \& alia, ad qua etiam ma iorum Germanix noftræ ciuitatum mercatores adire folent, per quos curari $\&<$ tranfmitti ad me fao cile poterit quicquid acceperint. Ego quog; eadem uia ad uiros doctos $\&$ liberales, quorum nomina \& uoluntatem cognouero, tum fcribendo, tum fi quid defidera= rint mittendo gratum me declarare porero. 


\section{DE PISCIBVS}

ET A QVATILIBVS

OMNIBVS LIBELLL

111. Nou1.

AVTHORE CONRADO GESsero Medico esphilofophia naturalis in terprete in Schola Tigurind.

1. SCHOLIA\&emendationes in $\mathrm{Ha}$ lieuticon P. Ouidij Nafonis.

11. A QV CATILIVM Animanium Enumeras tio zuxta Plinium, emendata ér explicatia,

Serie ititeraruni.

11. EOR VNDEM Nomenclator Germanicus longe copiofitsimus. Et alıa quadam ad Pifium hiftoriam pertinemis.

\section{TIGVRI APVD ANDREAM GESNERYAR.}

Figure 6. De piscibus (1556), title page, featuring four parts, each dedicated to a different person. Reproduced with permission from the Zentralbibliothek Zürich, shelfmark 18.2031. 


\section{4 CLARISSIMO VIRO BVRC. hardo Mythobio Medico \& Phi- lofopho nobilifsimo Con- radus Gefnerus me- dicús $S . D$.}

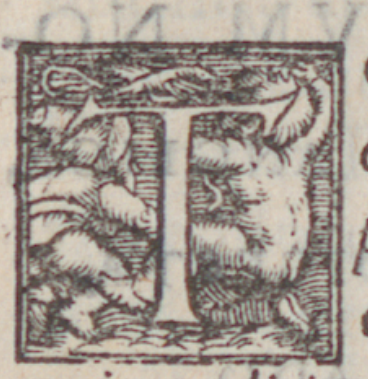

O MAS Erastus Heluctius. ciuis mens, vir in omni philofophia ac rei medica cientia preclaré doctus, wis nuper ad me l's teris ersditionem fimul o bumanitatem tuam, clarißime Mythobi, ßplendidé predicawit. Et icones aliquot animantium raras, Balthiciprefertim maris aquatilium, te poßidereadiecit, quas mihicommunicaturum te $\int$ is pollicitus, $\sqrt{2}$ qua commoditas tanto locorum interuallo mittendidaretur:cum ego in Helue tÿs non procul fummis alpibus of Rhenifors tibus habitem, tu veró in remota ad Septentriones Germanie parte, Munde (nifallor) cz nitate illustri ad nobile fumen Vi Jurgim $\int_{2}$ ta, apud Ericum illustrißimum ducem Brunfuicen fem honestit/3imo loco degas. Hacego benignitate tua excitatus, cü hunc de Ger. manicis Aguatilium vocabulis editionipara

rens 
saw a few years ago that your outstanding books on stereometry and the composition of the astronomical ring were received with great applause by learned men." 65 Philippe Glardon has argued that De piscibus with its assortment of fish lore in four parts was a "kind of open letter to existing and future correspondents, designed to display certain skills, such as drawing up lists, naming unknown species and even classifying them." 66 This dedication suggests that Gessner also saw it as an opportunity to show that he was a credible expert on fish in order to elicit material for the final volume of the Historia animalium. That volume was in progress at the time and appeared in 1558. But if Mythobius did respond to Gessner's dedication of 1556, it was not in time to be included in the list published in 1558 of those "illustrious men who kindly aided our efforts, several of whom are named here and there from the beginning in the previous volumes of the history animals or in this one." 67

Gessner wrote considerably more dedications than he published books: 57 of his publications contain a total of 102 dedications addressed to 127 individuals and six collectivities. ${ }^{68}$ For comparison, Erasmus composed 150 dedications across his 220 imprints. ${ }^{69}$ Only about one-quarter of Gessner's dedications, usually in high-profile folio volumes, were addressed to the kind of grandee that we have come to expect as dedicatees given the emphasis historians have placed on patronage: patricians and city council members in Zurich and a few other cities, imperial counselors and ambassadors, members of the Fugger family, and the great rulers of the day-Emperor Ferdinand, his son Maximilian, and Elizabeth of England. The bulk of Gessner's dedications were addressed instead to his peers in the republic of letters, including dozens of physicians and many professors, ministers, lawyers, a few merchants, and even some apothecaries. Gessner's attempts at seeking macro support did not succeed very well, in fact. Gessner declined Fugger's invitation to move to Augsburg and become his client (religious difference being an important factor in that decision, one suspects). We learn from the English state papers that Elizabeth I took offense at his dedication to her (even though it included a thirty-line Greek ode of Gessner's composition) and Gessner was only reimbursed his expenses. ${ }^{70}$ At least Gessner netted a coat of arms from Ferdinand I, though this was hardly a bankable reward..$^{71}$

Despite minimal support from grandees Gessner produced a remarkable number of expensively illustrated volumes of natural history and large collections of information on all kinds of topics. And he did so where other contemporaries failed. For comparison, Ulisse Aldrovandi, working one generation after Gessner, targeted exclusively the patronage of Italian cardinals to fund the publication of his illustrated natural histories, but only managed to publish two volumes in his lifetime - many more appeared after his death, paid for by the proceeds of selling his remarkable collection of naturalia. ${ }^{72}$ Gessner by contrast built his projects on the accumulated micro support of over 100 learned contacts who offered him hospitality on his occasional travels and sent him information and manuscripts, costly painted and engraved images, and priceless accounts of unique phenomena. For example, Gessner thanked Joannes Placotomus, a doctor in Danzig, for giving him two globules of oriental amber, which is so highly valued that "it was given in dowry to the king and queen of Portugal and burned in Lisbon for its most sweet and precious smell, of which there has been, as far as I know, no record until now."

Gessner thanked his contributors in his dedications (generally composing just one dedication per person, so he often included thanks on multiple counts) and in his lists of "those who helped" in his Historia animalium. Gessner first created this unique type of list in 1551 as an extension of the bibliography on quadrupeds that figured in the front matter of the volume. This "catalogue of learned men who to illustrate our work and the republic of letters either sent from somewhere images, names or descriptions of animals, or communicated them in person" comprised fifty-one names, including a number of Gessner's dedicatees and correspondents. ${ }^{74}$ The 
names were listed alphabetically by first name following the pattern of the bibliography to which the list was appended and, more generally, the arrangement of the Bibliotheca of 1545. Gessner specified place and profession in most cases. He provided similar lists for volumes 3 and 4 of the Historia animalium, with thirteen and twenty-seven names respectively, for a total of eighty-one people thanked in this way since a handful of names appeared on two of the three lists. ${ }^{75}$ Among those twice thanked (in 1555 and 1558) we recognize John Caius and learn of Hieronymus Massarius of Vicenza, a physician who lodged with Gessner for two months as a religious refugee in 1554 and who will make another appearance shortly. ${ }^{76}$

Gessner not only used the different books within one series (e.g., natural history) to provide regular updates as they became available. He also used the front matter of books of natural history to publicize new developments in his bibliographical projects. For example, the front matter of the Historia animalium of 1551 includes a "typographer to the reader," which issues a stern rebuke of those responsible for an unauthorized "elenchus," or abridgment, of Gessner's Bibliotheca published in Basel in that year. After announcing plans to publish an epitome of the Historia animalium (presumably the Icones of 1553), Froschauer added: "And as I say in passing, we would perhaps have given an epitome of the first volume of the Bibliotheca published from our business a few years ago, if we had not already heard that it was being made by someone else unbeknownst to us" - and (he notes) with many unfortunate omissions. ${ }^{77}$ The Historia animalium and the Elenchus appeared almost simultaneously, judging from their dedications dated August and September, respectively - clearly this message from Froschauer to his colleagues in Basel needed to go out at the earliest opportunity to lodge a strong protest against the Elenchus, which was publicized in print, but not (to my knowledge) pursued in a legal setting.

Similarly, four years later Gessner himself used the front matter to his natural history of birds to call attention to developments in his bibliographical projects. In his "to the reader" of his Historia avium Gessner announced the publication of the authorized epitome of the Bibliotheca, which appeared nearly simultaneously since both dedications were dated March 1555 . Gessner also announced there his plans to complete the Pandectae of 1548 and 1549 with a long-awaited volume on medicine. In particular Gessner explained that, "I recently wrote to my friend Hieronymus Massarius, the excellent Italian doctor, to collect the best and oldest authors of medicine in his Pandects, a work that he has already almost completed and that I hope will soon be printed at Basel." 78 In this case, by publicizing in print that this last volume of the Pandectae was in progress, Gessner likely sought to apply some pressure to Massarius to goad him into completing it. But Massarius ostensibly never did-the medical volume of the Pandectae announced as forthcoming in 1555 was never printed. Nonetheless, Massarius still appeared on the list of "those who helped" in 1558, so their relations had apparently not soured, at least by then.

In discussing in these paratexts works on topics different from the book at hand (e.g., bibliographical publications in works of natural history), Gessner may have assumed with good reason that the readership for both series of learned folio volumes presented considerable overlap. He also knew that a printed book was an excellent vehicle for broad publicity and so seized the opportunity to announce books forthcoming from the same printer, even on other quite different topics (fig. 8). Similarly, Valentina Sebastiani has shown how Froben disseminated news of Erasmus's edition of the New Testament in the paratexts of some of his other publications. ${ }^{79}$ Not surprisingly Gessner also made regular use of the books in the Historia animalium series to announce forthcoming additions to it. For example, the Icones animalium of 1553 announced that the "Latin volume of the History and description of other animals after the quadrupeds is already in press; and the first volume on quadrupeds has been translated into German, and is very soon 
Hist Anim I (1551)

$$
\text { ¿ }
$$

Icones (1553)—quadrupeds

$$
\text { ¿ }
$$

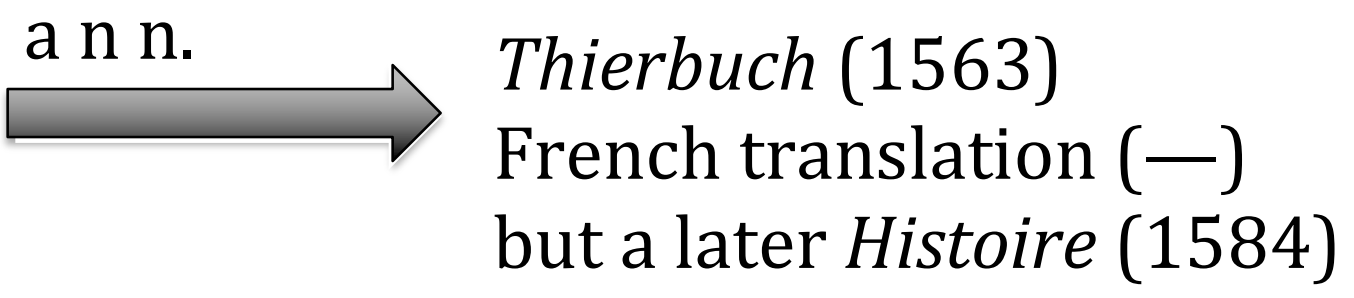

Elenchus (1551)

Hist Anim II (1554) —reptiles

+appendix on quadrupeds Hist Anim III (1555)—birds Icones avium (1555) - birds De piscibus (1556) —fish

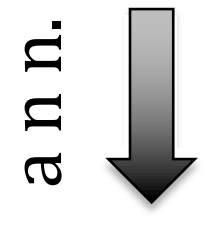

Hist Anim IV (1558) —fish

Bibliotheca (1545)

Pandectae 1-19 (1548)

Pandectae 21 (1549)

Uu es Epitome (1555)

Pandectae $20(-)$

Icones (1560) —quadrupeds, birds, fish 
being written in French." ${ }^{80}$ These announcements of future publications risked being inaccurate of course. The volume on reptiles indeed appeared the following year, but the German Thierbuch appeared a full ten years after it was announced in this way, and no French translation was ever published, although an Histoire des plantes of 1584 included an abridgment of Gessner's histories of animals, of which Gessner likely had no inkling since it appeared long after his death.

Gessner also called attention to his plans for publication in two extensive autobiobibliographies. The Bibliotheca and its sequels featured entries for Gessner (among the "Conrads") that were considerably longer than average - ten pages in 1545 and a full page or more in the Epitome and Appendix of 1555 in which most entries were just a few lines long. ${ }^{81}$ In 1562 Gessner also published a twenty-four-page booklet on his publications, De libris a se editis, couched as a response to a request from his English correspondent William Turner. ${ }^{82} \mathrm{He}$ used the longer texts (of 1545 and 1562) also as an opportunity to advertise works in progress or in planning, some of which came to fruition, others not. In 1545 Gessner mentioned his work underway on the history of animals along with an explicit invitation to a Maecenas to support the work-Gessner completed that project, although he remarked in the last volume that he never had a patron or Maecenas. ${ }^{83}$ But in 1545 Gessner also mentioned texts of Oppian and Eusebius, which he never published. In 1562 his list of works in progress included eighteen items, including the Oppian still on his to-do list-he explained that he had copied the text in Venice long before (presumably in the 1540s) and had used bits of it in his natural history but still hoped to publish it along with other Greek works on animals, "if the opportunity arose." 84

\section{Printing as Word Processing}

Publishing for Gessner was not the occasional and long-planned process that it was (and is) for many authors. Gessner was clearly a regular in many printing houses. He maintained especially close ties to Froschauer and his relatives Andreas and Jacob Gessner but also described noticing a manuscript he proposed to prepare for publication in the "abundant library" of Oporinus in Basel. ${ }^{85}$ Instead of the classic line in Renaissance prefaces that friends or students had urged publication, Gessner invoked the pressure of his printers, especially his relatives, who turned to him when they were in need of something to keep their press occupied or to flesh out a slim volume with an extra text. ${ }^{86}$ As Gessner explained in his auto-biobibliography of 1562, this pattern started in 1552 when Andreas and Jacob Gessner had first launched their business and Gessner gave them his book of remedies, Thesaurus Evonymi, to publish; but Gessner felt so rushed into print that he did not put his name on it until a few years later, after it had proved a success. ${ }^{87}$ The printers appeared in Gessner's telling as eager takers of the manuscripts Gessner proposed, but they no doubt also supplied him with projects and exceptional access to manuscripts and recently published books. When Gessner recommended cutting and pasting from printed books he probably had in mind not commercially viable copies, but rather copies that had served as exemplars from which to compose a new edition, marked up in the process and ready to be discarded, which he could have picked up on one of his visits to printers. ${ }^{88}$

A printed text was a tool for Gessner. Each new publication in the series of his naturalhistorical books was the object of revision and augmentation in the next one. This same attitude is visible in books that were never published in revised form, when Gessner nonetheless recorded his plans for revisions - changes, additions, and subtractions - by annotating his own copies of his books. ${ }^{89}$ Print served not only as the substrate of revisions, but as a means of annotation too when Gessner occasionally cut and pasted printed passages onto a page to record revisions. For example, Gessner pasted into his copy of his dialogues urging the expurgation of Martial a section from Propertius in which the poet decries "the hand that first painted obscene pictures, placing filth in 
chaste homes for all to see," which Gessner presumably viewed as further support for his argument for censorhip (fig. 9). ${ }^{90}$ In the case of his annotated copy of the Bibiotheca universalis, the changes Gessner made by crossing out some sentences and inserting a new printed section occurred at the stage of a proof copy since the version of the text that was diffused contained the new passages instead of the old ones crossed out. The changes involved replacing some sharp criticism of a recent edition of a work by the Syriac physician Ioannes Serapion, published in Basel in 1543, with a more anodyne discussion of the confusion of names due to Serapio's being called John Damascenus (fig. 10). In the deleted sentences Gessner complained of interpolations and perversions of the text, and he warned the reader specifically against the work of Albanus Torinus, a physician and professor at Basel, who was responsible for part of the work. ${ }^{91}$ Gessner may be alluding to this late decision to omit his criticism when he noted in the front matter of the Bibliotheca that friends had dissuaded him from denouncing by name some who, "although they wish to be counted among good and learned men, change the titles and interpolate the contents of works so they are sold as if they were new books"a crime that Gessner promised to make them regret, even if (I surmise) he gave up on his initial plan to shame them in print. $^{92}$

Even when there were no plans for a later edition in which to implement revisions, Gessner was always preparing for one. Just as he continued to invite contributions on a topic like linguistic diversity on which he never published again, so too any printed book of his was an opportunity to prepare for another version. Similarly, Henry Woudhuysen has observed of some near-contemporary English poets that "a first printing was only an intermediate stage in the creation of a work ... [once a work was printed] the process of revising, rewriting, and rearranging could properly begin, sometimes almost at once." 93 The English ecclesiastical historian Matthew Parker took malleability in print to an extreme, generating at his own press in London as many different versions of his $D e$ antiquitate Britannicae ecclesiae (1574) as there are extant copies, by rearranging and changing the contents of the folio-sized booklets that comprised the work. ${ }^{94}$ Tony Grafton has proposed suggestively that printing functioned for these writers like word processing, only with slow updating speeds. Printing was a tool not only for diffusion, but also for the process of composing texts, at least for those who had especially easy access to the technology-like Gessner, given his close contacts with printers, or Parker who owned his own press.

\section{CONCLUSION}

Gessner always had multiple projects underway and many more in waiting. He could respond on a dime to requests from his favorite printers to contribute a short text to round out a work in press, to edit a manuscript left unfinished at someone's death, or to combine multiple elements into a publishable book. And he generally used the occasion to issue a few messages of his own-to thank contributors to his projects or to plead for more materials, to announce an update on work in progress, or to advertise his willingness to entertain new proposals.

We can watch Gessner's method of working on the fly, finishing the end of a book while the beginning was already being printed, and creating works that are more miscellaneous and multi-authored than a simple attribution to Gessner suggests by looking at one text particularly rich in disparate elements. In 1561 Gessner published an edition of manuscripts by the not so recently deceased botanist Valerius Cordus (1515-44), which had been handed down from the uncle of the deceased to Ioannes Placotomus and on to Gessner, who saw it through publication in Strasbourg, not completely happily judging from the complaints he made to two friends about the printer. ${ }^{95}$ Cordus's commentaries on Dioscorides occupied the bulk of the title page, but the work also included eight other sections, to each of which Gessner supplied a dedication (fig. 11). A long (250-page) "historia plantarum" by Cordus was followed by a short (eight-page) discussion by 
facias? ut homo oft, itamorem gerds. DEM. Sas tis lam fatis te syre et excufationes bafce tuas pera noui. V.erü fcio te etiam inftigare Mitionè, ne gna tum ab iftis ftudijs remoueat. Nam tu qui meliora non didiceris, ex nequitijs huiuf modi, quas egregie calles, fi dis placet, lucrum tibi comparare fatagis. Vinde tandem tue fomenta gule fuppeterent, nif defenderes bec ßpurca tam fedulo? $S Y R$. Lam iam feruulus Mitionis nos wocatos feftinanter accedere iußit. DEM. Vide ut mentitur impudens caput: fic nullü uitium olum eft. lam hortatus fuerat Ae= fchinum ad deambulationem, nunc aliud fingit. AES C H. Eamus. SYR, Vale Demea. Sed en tibi fratrem buc accedentem, cum illo age, ut lubet. Mea in bacre nulla eft cul

pa. DEM. Non tandem bine abitis in malam reme.

\section{AESCH.Exmus} inquam.

\section{4}

Que manus obfceenas depinxit prima tabcllds,

Et pofuit casta turpia uifa domo, Illa puellarum ingenuos corrupit ocellos,

Nequiticáq; fux noluit effe rudes. Ab gomat in terris ifa qui protulit arte. Iurgia fub tacita condita latitia. Non iftis olim uariabant tecta figuris,

cumparies nutlo crimine pictus erat.

Figure 9. Martialis epigrammata (1544), in Gessner's own annotated copy. Reproduced with permission from the Zentralbibliothek Zürich, shelfmark 7.377. 
I O $\mathrm{A}$ N. $s$.

nis, 8 de agritudinibus matricis, 6 Defebribus, 7 Deantidotis, ideft cuiufuis generis medicamentis fecundum genera. Imitatur autern precipue in hoc opere Galeni libros nxtrè rówous, ubi locis affectis à capite ad pedes medetur.

Hilibri practica feu breuiarij Serapionis Bafilex etiam nuper impreffi funt, apud Henricum Petrum, 1543, in fol. duplo ferè chartarum numero, quàm prius in Italia exiuerat; quamuis ultimus liber de antidotis non fit adiectus. Nam egrese $7^{i}$ gitts itte paraphraftes, Albanus Torinus nouo titulo plaufibilem Bafilieñ. aditionë fecit, Iani Damafceni Decapolitani nomine inducto pro Ioan. Serapione, \& ab ini. tio aphorifmos etiam antehac Ioanni Damafceno infcriptos adiecit, tt mintss do. lum olfaceret Leefor, \&x ultimü librtm de antidotis omifit: cateros in medio miris medis interpolauit : nam \& tranfponit ordinem: $\&$ in illis libris, ubi Gerardi Cre monenfis translationem fe relinquere fatetur, plurima mutat, \& fueseentenes ane nectit; ae probarbaris fape Gerarđtuocabulisipfe-affeetata \& obfoletainfarcit: in illisurero, quos de integro bellula paraphrafi furatrertit attepotius peruertit, uocabu tis immorattrr, prolixtrs eft de induftria, \& tanquam feholia protyronibus inferat, gratiambretritatis quam atrettpattus erat Serapion amittit. Sed nihilgratrius dio eam, quamuis uchementer milhi difplieet fucum emptoribus fieri, $\& \mathrm{ab} / \mathrm{q}$ fructu næniashtritumodi \&s braffieam bifcoctam miferis Leetoribus obtrudi. Siquidem \& ipfe ditrerforum authorum opera effe hucufq̧ ratus (nam ne fupra quidẽ cum de Lano \& Ioanne Damafceno fcriberem, aliter exiftimabam) utrüq; mihicompa. kare, \& utriuffeps lectionitemporis nonnihil dare iam decreurerä, quod pofthac minime faciam:maloenim Gerardi translationem integram, hominis utcunq; $A_{1}=$ bicæa lingux periti, \& fimplicem Serapionis fententiam, quàm Albani, qui ne Iota guide cius lingure callet, paraphrafes inani oftentatione plenas, 8 undequaç con farcinatas. In epiftola nuncupatoria fcribit fe nuper hocopus in bibliotheca qua dam inueniffe: nimirum ut fiquis rem deprehenderet, ignorantia potius publicata prius ædittonis, quàm aftrtia illieiendiemptores, feciffe quod fecit excurfari poffet, Opinor atrtem etiam in Garioponto \& Alexandrollatro, \& alifjs quibufdam, non f diffrnitia machinatumeffe: quare Lef̂rẽ medicinae ftudiofum admoneo, fiquid z proficeretrelit, libros Albaninomine infignitos nemagnifaciat,

IO A N.Sermoneta medicus docuit Bononix, anno 1430. mulca fcripfit; è quibus ego reperi duntaxat, Quaftiones fubtiliffimas in aphorifmos Hippocratis. Qua: ftiones in Technen Galeni. Symph. Champerius, Vtrũ o̧opus impreffum eft in Italia. Campodunañ.

Io A N, Serranus collegit Dictionarium Latinogermanicum, quo fingulæu uoces La,

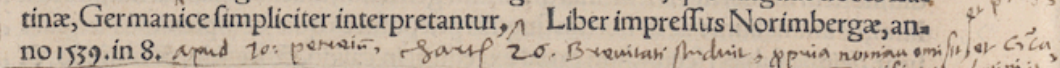

in tyuom gex aliat nopititapop

auforib] Copounts.

$10 \mathrm{~A}$ N.Sichardus, natione Germanus, egregios aliquot authores noftra atate recos gnouit 8 in lucem protulit, quorum aliquot Bafilex impreffos uidimus: nempe Quintiliani oratorias inftitutiones ab eo caftigatas, Iuftini hiftoricilibros uario rum exemplarium collatione recognitos, Aurelij Prudentij opera fcholips infu= per illuftrata, impreffa apud Hen, Petrum, 1540. ut fupra dixi.

IO A N. Siliceus quidam reliquitaliquid fcriptum in arithmetica, ut meminit Ludouia cus Viues lib, 4. de tradendis difciplinis,

Io A N. Simonetæ, natione Calabri, rerũ geftarum Francifci Sphortiæ Mediolanen. fiũ ducis libri 3 i,impreffi Mediolani, anno 1486, in fol,chartis nonaginta quaturor, Ex prafatione authoris ad Ioan. Galeatium Mariam Sphortiam Mediolanenfium " ducem Francifci Sphor,nepotem, Francifci Sphortix atui tui, quarti Mediola" " neñ. ducis iunctiffimi res geftas poft obitũ proauti tui Sphortix, pauloọ́ altius pro

" rerum cognitione repetens, carptim fcribere, \& quo breuius liceat recenfere infti,

" tui, ab anno incipiens quarto \&uigefimo ufक̧ in quartum $\&$ quadragefimum fu= Hilibri practica feu breuiarij Serapionis Bafilex etiam nuper impreffi funt,
apud Henricum Petrum, 1543 . in fol, duplo ferè chartarum numero, quàm prius pra mille. in Italia exiuerat:quamuis ultimus liber de antidotis non fit adiectus. Nam para. N6.Torinus. phraftes (ut fe infcribere uoluit)Albanus Torinus nouto titulo plaufibilem Bafilien fem æditionẽ fecit Iani Damafceni Decapolitani nomine inducto pro Ioanne Se. rapione, $\&$ ab initio aphorifmos etiam antehac Ioanni Damafceno infcriptos (ne. fcio quàm recte, in libello feorfim ædito)adiecit, cęteros in medio interpolauit:nam \&ordinem tranfponit, \& in illis libris, ubi Gerardi Cremonenfis translationẽ fe re linquere fatetur, plurima mutat. In epiftola nuncupatoria fcribit fe nuper hoc opus in bibliotheca quadam inureniffe, tanquam nefciuerit idem prius publicatũ fuiffe, ac medicis omnibus notifimum. 


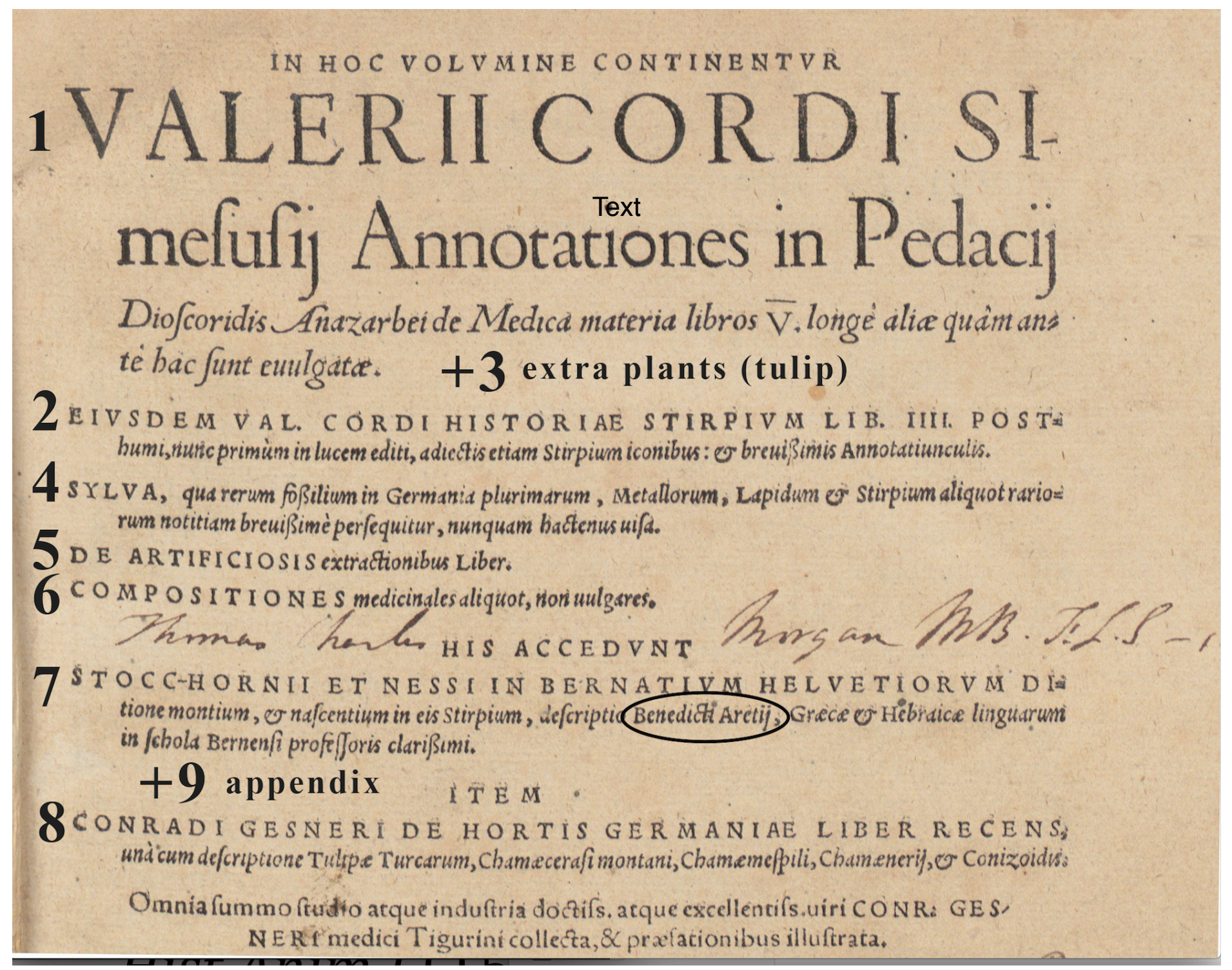

Figure 11. Valerius Cordus, Annotationes in Dioscoridis De Materia medica libro V (1562), title page, annotated to show the nine texts included in the book. Reproduced with permission from ETH-Bibliothek Zürich, Alte und Seltene Drucke, shelfmark Rar 9149 q, with my annotations in Photoshop. 
Gessner of additional plants, untitled, but which has attracted the attention of historians because it featured the first representation of the tulip in Europe. ${ }^{96}$ Then Gessner edited three short works by Cordus - on metals, on "artificial extractions" (e.g., distillation), and on medical compounds. Next came an eight-page description of Mount Stockhorn in the Bernese Alps, composed by Gessner's friend Aretius, professor of Greek and Hebrew in Bern, who had reportedly asked Gessner to write the dedication to the text and publish it. Just as the collection seemed to be winding down in this series of short pieces, Gessner introduced his own 100-page catalogue of the gardens of Germany, arranged in alphabetical order. But that text proved hard to finish. After the "finis" marker (a much ignored piece of paratext recently given its due by Bill Sherman) Gessner continued to add to it lists of plants in notable gardens - those of Ioannes Schmidlapp in Wittemberg, Petrus Michaelus in Venice, and the duke of Florence. ${ }^{97}$ This last list of just ten plants was clearly added after the rest of the page was set, and extends into the margin (fig. 12). After four iterations of "finis" in just two pages Gessner launched into a twenty-four-page appendix to his discussion of German gardens. In that dedication, to the Veronese pharmacist Francesco Calzolari, Gessner apologized for not having included Calzolari's plants in the work he had just finished, "since my book on the gardens of Germany to be printed at the end of the works of Valerius Cordus was not at hand and could not be recalled, because the printer was rushing to the end of the work." 98 After the appendix Gessner included closing paratexts: an unusually long list of errata (in six pages), born from the combination of haste in production and concern for correction, followed by a poem in honor of the upcoming wedding of the daughter of the dedicatee Gessner had initially chosen but who had died in the meantime (Ioannis Ralla), as he explained in the dedication that was actually printed (addressed to Ralla's young son, who is not named). The book finally ended with word indexes for three of Cordus's works.

The result is a fine folio volume, which transmits botanical and medical manuscripts that might otherwise have been lost - a monument of the kind printing was so good at producing — but one that is larded with the signs of Gessner's immediate engagement with the myriad people in his social network. These included personal contacts - friends like Aretius or the bereaved relatives of a scholar he knew (the son was a dedicatee, the daughter the object of the poem); socially prestigious connections, like the owners of gardens that Gessner kept adding at the last minute as if worried about offending someone by omitting them; and scholarly contributors, notably the nine other dedicatees, whom Gessner thanked for information already sent or anticipated. These comprised five doctors, including the high-ranking imperial physician Stephanus Lauraeus; two pharmacists; and one minister - each of whom Gessner thanked as in so many other cases for sharing information, variously about mountain plants and roots, medical remedies, rare and foreign plants in the emperor's gardens, and the unique experience of the amber burnt for the king and queen of Portugal. All of these Gessner included in the limelight of this publication. What Gessner could offer in return was the impacts of publication - both in the immediate context of spreading thanks and credit (and occasional criticism and subtle pressure) fast and far among contemporaries, and in the long-term impact of carrying these glimpses of the workings of late humanist scholarship across almost 500 years. 


\section{CATALOGVS PLANTARVM \\ HORTI CLARISSIMI VIRI PETRI MICHAELIS ciuis Veneti,in uico $S$.Geruafii:quefnlta. licè friptum ab amico ante annos quatuor ferè accepi}

Acanthus radicis glandife= Eupatorium Mefua è Syria. Ofyris flore corruleo aut nio re. Faba Aegyptia. laceo.

Aegoletbros plinij. Fafeolus purpureus Indicus. Panaces Chironium Theo= Alaternus Plinij.

Alimus Crateue. Ficus Aegyptia. phrafi.

Alliaria alpina. Fonogrecum recentiorum. Polycnemum.

Arifolochia $r$. Folium, Diofcoridis nimin Pyramidalis quedamplane

Actea Plinij.

Apalates uerus. rum. Galeti, firct quid. uadrifolium.

A/phodeli precies alique.

Balanus Myrepfica. Gingidiu lego. Rhaponticum Ro/e mo/chate, fine/pinis.

Eutracbium, Ranunculifpe Hy acinthus, Tulipa Turcas Sanicula fomina. cies.

Bellio Plinij. rum, wel Lalle. Scbaftus ex Oriente.

Carelice, (cu Cinnamomi uul Hyffopus quadam, uel Ser = Sedi plures Ppecies. gódicti, folia.

Cardues nobilis.

Carus. pyllum rectum.

Lichen Plinil. Lilium Alcxandrinum. Sementina ex Oriente. Sion Plinij. Sifari plures fpecies.

Caryophy Dorum ex Oriens = Lonchitis prima et fecunda. Smilax lenis ex Creta. te folia. Lunaria Boriffa, pecies Cen Spina ceruina.

Cedronslla, fecies Nigelle. tauri) minoris. Staphylodendron puto: $n$

Cepex. Lycium fecundum Indicum. Italicè foributur Albero

Cherfium (fortè Corfium, Mandragoras mas. ds l' uus qrodeft radix Loti Aegy Mclongena uel Mala infa= Tomentaria è Creta. Ptic) Theophrafti.

Chondrilla Plinij.

Coryfogonum.

Cornioli, Lutea Pliniy.

Colocynthidis duo genera.

Datuses Creticus.

Didiminus marinus.

El stine fectunda.

Epimedium. nopinofa.

Mufa.

Narciffus flore multiplici, è Traßi uel Dulcichini. Verbafcum uif cofumè Crea

Narciffus luteus, pecies $\mathrm{T} u$ uarie. lipe Turcice. Alius lus teus atutumnalis, fpecies Colchici.

Nardus montanduera.
CELEBRATVR ET Ducis Florentini hortus:

in quo prater alia pula chra alutrard, bece $=$ tiam vifuntur;

ut audio.

Myrtuslaured.

Laturocerafus.

Lablurnum.

Solanum fomniferum uerü:.

Genifte fpecies irifolia, quã aliquinon rectéprocy tifo accipiunt.

Thapfia.

Ferila.

Smilaxlenis uerd, quam et in monte Atho fibi ui fam Bellonius ait.

Caprifoliü Memphiticü,ut Bcllon. Hocat, quodetrix ca Memphidem Acgypti in sepibus prowenit, apo cyno fimile, liquorces tiam albo mnanas, wt il lud croç̧o: fed amplexi caule or in altum af ccria dens: fpecies Smilacis le uis aut apocyni.

Herbabaccifera, folio silis quaftri Fuch/y, orc.

FI N IS

\section{CONRADI. GESNERI APPENDIX}

LIBRI SVI DE HORTIS GERMANIAE, AD FRAN= cifcum Calccolarium, pharmacopolam Veronena

fem ad infigne Campanx aurex.

$\mathrm{P}_{\mathrm{b}}^{\circ}$

S T QV A M Dominicus Monthifatris, (uir non folum felici artis nsedice ufu fummus, (ed etiam phis

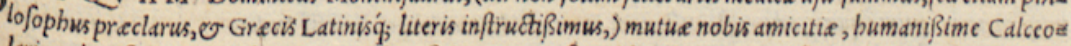
Lari,author fuit, multa ab eo tempore beneficia tua copiofe e liberaliter in me collata percepi. Quacunque

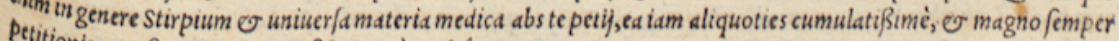
mitonis mee fonore ad me mififi : uti cum alias, tum proximo uere proprio ad te nuncio tam longinquo itinere Perp. qui Stirpes aliquas rariores tutè citó; abs te mifí adferret, benignißimè fum expertus. Et quanquam ego Porterum uicißim mitto, (quoniam regio noffra parcißima fert, $\mathcal{V}$ ego negocijs alijs occupatißimus operam rci tircen i, ut uellem, dare non po/fum:ac wix unus aut alter pretgr me apud nos huic cultui deditus eft, ) non tamen ide

"irco defiftis, o noua fubinde donas, quscusq́; occurrunt. quod quidem bonitatis tue, $\mathcal{F}$ fyncere amicitie, nori

algais illius, que utlitatem magis quam uirtutem achoneftatem fpectat, argumentum illuftre cft. Exigua certe $\mathrm{V}$ u

Figure 12. Valerius Cordus, Annotationes in Dioscoridis De Materia medica libro V(1562), fol. 288r, the last page of Gessner's Horti Germaniae and beginning of the appendix. 


\section{CAPTIONS}

Figure 1. Graph of Gessner's publications by date and format.

Figure 2. Icones animalium (1553), appendix, page 59, featuring images delayed by the carver. Reproduced with permission from the Zentralbibliothek Zürich, shelfmark AW 1.

Figure 3. Icones animalium (1553), sig. $[\mathrm{H} 5]^{\mathrm{r}}$, following the appendix, Gessner's apology for images that were not included. Reproduced with permission from Zentralbibliothek Zürich, shelfmark AW 1.

Figure 4. Historia animalium II (1554), appendix, page 4, featuring the white Scottish bison, which Gessner apologized for omitting in 1553. Reproduced with permission from the Zentralbibliothek Zürich, shelfmark 5.2.

Figure 5. Historia animalium III (1555), sig. [a6] ${ }^{\mathrm{r}}$, a list of the learned men who helped, with instructions on how to send further information to Gessner. Reproduced with permission from Zentralbibliothek Zürich, shelfmark 5.2,2.

Figure 6. De piscibus (1556), title page, featuring four parts, each dedicated to a different person. Reproduced with permission from the Zentralbibliothek Zürich, shelfmark 18.2031.

Figure 7. De piscibus (1556), page 94, the dedication to Burchard Mythobios of Gessner's Aquatilium animantium nomina Germanica et anglica, serie literarum digesta. Reproduced with permission from the Zentralbibliothek Zürich, shelfmark 18.2031.

Figure 8. Chart of the references that Gessner made to forthcoming books in his front matter.

Figure 9. Martialis epigrammata (1544), in Gessner's own annotated copy. Reproduced with permission from the Zentralbibliothek Zürich, shelfmark 7.377.

Figure 10. Bibliotheca universalis (1545), fol. 454v, in Gessner's own annotated copy. Reproduced with permission from the Zentralbibliothek Zürich, shelfmark Dr M 3.

Figure 11. Valerius Cordus, Annotationes in Dioscoridis De Materia medica libro V(1562), title page, annotated to show the nine texts included in the book. Reproduced with permission from ETH-Bibliothek Zürich, Alte und Seltene Drucke, shelfmark Rar 9149 q, with my annotations in Photoshop.

Figure 12. Valerius Cordus, Annotationes in Dioscoridis De Materia medica libro V (1562), fol. $288^{\mathrm{r}}$, the last page of Gessner's Horti Germaniae and beginning of the appendix. Reproduced with permission from ETH-Bibliothek Zürich, Alte und Seltene Drucke, shelfmark Rar 9149 q. 


\section{BIBLIOGRAPHY}

Algazi, Gadi. "At the Study: Notes on the Production of the Scholarly Self." In Space and Self in Early Modern European Cultures, ed. David Warren Sabean and Malina Stefanovska, 1750. Austin: University of Texas Press, 2012.

Baldi, Diego. "Conrad Gesner, i Loci Communes dello pseudo Massimo Confessore e la Melissa del monaco Antonio." Bibliotheca 1 (2014): 19-61.

Bardon, Henry. La Littérature latine inconnue. Paris: Klincksieck, 1952.

Bembo, Pietro. Oratio pro Litteris Graecis. Ed. and trans. N. G. Wilson. Messina: Centro Interdipartimentale di studi umanistici, 2003.

Blair, Ann. Too Much to Know: Managing Scholarly Information before the Modern Age. New Haven: Yale University Press, 2010.

. “Conrad Gessner's Paratexts.” Gesnerus 73.1 (2016): 73-123.

Bloemendal, Jan. "Topical Matters in Dedicatory Letters of Latin Plays in the Early Modern Netherlands." In Between Scylla and Charybdis: Learned Letter Writers Navigating the Reefs of Religious and Political Controversy in Early Modern Europe, ed. Jeanine De Landtsheer and Henk Nellen, 203-15. Leiden: Brill, 2011.

Caius, John. De canibus Britannicis. London: Guilielmus Seresius, 1570.

Clark, Frederic. "Dividing Time: The Making of Historical Periodization in Early Modern Europe." PhD diss., Princeton University, 2014.

Dane, Joseph A. The Myth of Print Culture: Essays on Evidence, Textuality and Bibliographical Method. Toronto: University of Toronto Press, 2003.

Dannenfeldt, Karl H. "The Wittenberg Botanists during the Sixteenth Century." In The Social History of the Reformation, ed. Lawrence P. Buck and Jonathan W. Zophy, 223-46. Columbus: Ohio State University Press, 1972.

Delisle, Candice. "Une correspondance scientifique à la Renaissance: Les Lettres Médicinales de Conrad Gesner." In Réseaux de correspondance à l'âge classique (XVIe-XVIIIe siècle), ed. Pierre-Yves Beaurepaire, Jens Häseler, and Antony McKenna, 33-43. Saint-Etienne: Publications de l'Université de Saint-Etienne, 2006.

. “Accessing Nature, Circulating Knowledge: Conrad Gessner's Correspondence Networks and His Medical and Naturalist Practices." History of Universities 23.2 (2008): 35-58.

Durling, Richard. 'Conrad Gesner's Liber amicorum 1555-65.” Gesnerus 22 (1965): 134-59.

Eisenstein, Elizabeth. The Printing Press as an Agent of Change: Communications and Cultural Transformations in Early-Modern Europe. Cambridge: Cambridge University Press, 1979.

Erasmus, Desiderius. Adagiorum chilias secunda. In Opera omnia, ordo 2, tome 3. Ed. M. Szymański. Amsterdam: Elsevier, 2005.

Facetten eines Universums: Conrad Gessner 1516-2016. Ed. Urs B. Leu and Mylène Ruoss. Zurich: Verlag Neue Zürcher Zeitung, 2016.

Gerritsen, Johan. "Printing at Froben's: An Eye Witness Account." Studies in Bibliography 44 (1991): 144-63.

Gesnerus 73.1, special issue: Conrad Gessner 1516-2016. Ed. Vincent Barras and Hubert Steinke, 2016.

Gessner, Conrad, comp. Actuarius. De medicamentorum compositione. Gessner, Succiduorum medicaminum tabula. Basel: J. Wynter, 1540. 8vo.

, comp. Actuarius. De differentiis urinarum. Gessner, Universalis doctrina Galeni. Gessner, Sylva experimentorum Galeni. Zurich: Froschauer, 1541a. 8vo. 
. Historia plantarum. Basel: J. Wynter, 1541b. 8vo.

De Lacte et operibus lactariis. Zurich: Froschauer, 1541c. 8vo.

trans. Michael Ephesius. Scholia in Aristotelis Libros. Scholia de longitudine et brevitate vitae. Scholia de divinatione per somnum. Nicolaus Leonicus Thomaeus, In Aristotelis De partibus animalium. Basel: B. Westhemer, 1541d. 8vo.

. Catalogus plantarum. Zurich: Froschauer, 1542a. 4to.

. Apparatus et delectus simplicium medicamentorum. Lyon: Frellon, 1542b. 8vo.

Moralis Interpretatio errorum Ulyssis Homerici. Gessner, trans., Commentatio de nympharum antro (Porphyry). Lucubratio Procli Lycii. Zurich: Froschauer, 1542c. 8vo.

, comp. Porphyrii institutiones. Aristotelis Categoriae. De interpretatione. Trans. and annot. Joachim Perion. Psellus in quinque Porphyrii voces. Georgii Pachymerii de sex philosophiae definitionibus. De decem praedicamentis. Michael Pselli Paraphrasis in librum Aristotelis de Interpretatione. [Gessner], Compendium de syllogismis authoris incerti. Basel: R. Wynter, 1542d. 8vo.

, trans. Stobaeus, Sententiae ex Thesauris Graecorum. Cyri Theodori prodromi amicitia exulans. An virtus doceri possit dialogus incerti authoris, etsi vulgo Platoni inscribatur. Zurich: Froschauer, 1543a. fol.

. Enumeratio medicamentorum purgantium. In Brasavola, Examen omnium catapotiorum sive pilularum. Zurich: Froschauer, 1543b. 8vo.

, trans. Heraclides Ponticus. Allegoriae in Homeri Fabulas. Basel: Oporinus, 1544a. 8vo. , ed. Martialis Epigrammata. . . His accesserunt Dialogi tres. Zurich: Froschauer, 1544b. 8vo.

. Onomasticon. Basel: Curio, 1544c. fol.

, ed. Antonii Thylesii. Opuscula aliquot. Basel: Oporinus, 1545a. 8vo.

Bibliotheca Universalis. Zurich: Froschauer, 1545b. fol.

. Lexicon Graecolatinum. 4th ed. [first to list Gessner]. Basel: Curio, 1545c.

, ed. Sententiae Antonii et Maximi [Greek]. Zurich: Froschauer, 1546a. fol.

, trans. Sententiae Antonii et Maximi [Latin]. Tatiani Assyri oratio ad Graecos. Zurich: Froschauer, 1546b. fol.

, ed. Ermolao Barbaro. Naturalis scientiae totius compendium. Accessit Wildenbergii . . . in Aristotelis physicam epitome. Basel: Oporinus, 1548a. 8vo.

. Pandectae. Zurich: Froschauer, 1548b. fol.

Partitiones theologicae. Zurich: Froschauer, 1549a. fol.

, ed. Galenus. Opera. Basel: Froben, 1549b. fol.

Onomasticon. 2nd ed. Basel: Curio, 1549c. fol.

, ed. Aristotelis. Opera omnia. Basel: Bebel and Isingrin, 1550a. fol.

. Galeni brevis denotatio dogmatum Hippocratis. In Galeni aliquot opuscula. Lyon: Rovillius, 1550b. 8vo.

Historia animalium I: De quadrupedibus viviparis. Zurich: Froschauer, 1551a. fol.

. Elenchus. Basel: Oporinus, 1551b. fol.

, ed. Hieronymus Tragus. De stirpium . . facultatibus. Trans. David Kyber. Strasbourg:

Wendelin Rihel, 1552a. fol.

Thesaurus Euonymi Philiatri. Zurich: A. Gessner and Wyssenbach, 1552b. 8vo.

De Germaniae et Helvetiae Thermis. In Thomas Iunta, De Balneis. Venice: Iunta, 1553a. fol. 
, ed. David Kyber. Lexicon rei herbariae. Gessner, Tabulae in collectionum per xii menses. Strasbourg: Rihel, 1553b. fol.

. Icones animalium. Zurich: Froschauer, 1553c. fol.

. Historia animalium II: De quadrupedibus oviparis. Appendix Historiae quadrupedum. Zurich: Froschauer, 1554. fol.

. De praestantia et antiquitate chirurgiae. In Chirurgia. Zurich: Andreas and Jakob Gessner, 1555a. fol.

. Historia animalium III: De avium natura. Zurich: Froschauer, 1555b. fol.

Appendix. Zurich: Froschauer, 1555c. fol.

Epitome. Zurich: Froschauer, 1555d. fol.

. Icones avium. Zurich: Froschauer, 1555e. fol.

. De raris et admirandis herbis. Descriptio Montis Fracti sive Montis Pilati. Ioannes du Choul, Descriptio Pilati Montis in Gallia. Ioannis Rhellicanus, Stockhornias. Zurich: Andreas and Jakob Gessner, 1555f. 4to.

. Enchiridion rei medicae triplicis. Zurich: Andreas and Jakob Gessner, 1555g. 8vo. Mithridates. Zurich: Froschauer, 1555h. 8vo.

. Sanitatis tuendae praecepta. Zurich: Andreas and Jakob Gessner, 1556a. 8vo.

. De piscibus et aquatilibus omnibus libelli. Catalogus aquatilium ex Plinio. Aquatilium . .

. nomina Germanica et Anglica. De fictis in Germanica lingua aquatilium nominibus.

Zurich: Andreas Gessner, 1556b. 8vo.

, ed. princeps and trans. Aelianus. Opera. Zurich: Andreas and Jakob Gessner, 1556c. fol.

, trans. Athenagoras. Geneva: Henri Estienne, 1557a. fol.

. De stirpium aliquot nominibus. Padua: Perchacinus, 1557b. 8vo.

. Historia animalium IV: De piscium . . natura. Zurich: Froschauer, 1558. fol.

, ed. princeps. Marcus Aurelius Antoninus. De vita sua. Marini de vita Procli. Zurich: Andreas Gessner, 1559a. 8vo.

, trans. Hannonis Carthaginensium ducis navigatio. In Leonis Africani de totius Africae descriptio. Zurich: Andreas Gessner, 1559b. $16 \mathrm{mo.}$

, ed. and comm. Xenocrates de alimento ex aquatilibus in Iani Dubravii. De piscinis, Zurich, 1559. Zurich: Andreas Gessner, 1559c. 8vo.

. Icones animalium. 2nd ed. Zurich: Froschauer, 1560a.

. Nomenclator . . Icones Animalium aquatilium. Liber II. Ordo II, tomus II, de reliquis aquarum dulcium alumnis. Accessio de Germanicis . . nominibus. Zurich: Froschauer, 1560b. fol.

. Icones avium. 2nd ed. Zurich: Froschauer, 1560c. fol.

, ed. and comp. Valerius Cordus. Annotationes in Dioscoridis de medica materia libros $V$. Valerii Cordi historia plantarum. [untitled extra plants]. Valerius Cordus, Sylva observationum variarum. De artificiosis extractionibus. Compositiones medicinales aliquot. Benedictus Aretius, Stocc-hornii . . montium descriptio. Gessner, Horti Germaniae. Appendix de hortis Germaniae. Strasbourg: Josias Rihel, 1561a. fol.

, intr. Josua Maler. Die Teütsch spraach. Josua Pictorius. Dictionarium Germanicolatinum. Zurich: Froschauer, 1561bs. 8vo.

. Historia et interpretatio prodigii. Zurich, 1562a. 8vo.

, ed. and trans. Cassius Iatrosophista. Naturales et medicinales quaestiones. Zurich: Jacob Gessner, 1562b. 8vo.

, intr. Claudius Galenus. Opera omnia. Basel: Froben, 1562c. fol. 
, ed. Sante Arduino. De venenis. Ponzetti, De venenis. Basel: Henriceptri and Perna, 1562d. fol.

. De libris a se editis epistola ad Guilielmum Turnerum. Zurich: Froschauer, 1562e. 8vo.

, ed. Valerius Cordus. Stirpium descriptionis liber V. Strasbourg: Rihel, 1563a. fol.

. De anima. In Ioh. Lod. Vives, De anima et vita. Vitus Amerbach, De anima. Melanchthon, De anima. Zurich: Jackob Gessner, 1563b. 8vo.

, ed. Jodocus Willich. Ars magirica hoc est coquinaria. Zurich: J. Gessner, 1563c. 8vo.

. Lexicon in Hippocratem. In Henri Estienne, Dictionarium medicum. Geneva: Henri Estienne, 1564. 8vo.

, ed. Dioscorides. De curationibus morborum. Strasbourg: Rihel, 1565a. fol.

, comp. De omni rerum fossilium genere. Kenntman, Calculorum . . in corpore . . genera

xii. De metallicis rebus . . ex schedis Georgii Fabricij. Severinus Goebelius, De succino.

De bitumine, by unspecified learned medicus. Valerii Cordi de Halosantho, cum corollario

Gesneri. Sancti Patris Epiphanii . . . de XII gemmis, cum Corollario Gesneri. Franciscus

Rueus, De gemmis aliquot. Gessner, De rerum fossilium, lapidum et gemmarum ... figuris

et similitudinibus. Zurich: Jakob Gessner, 1565b. 8vo.

, intr. Jacques Houllier. Viaticum novum. Zurich: Froschauer, 1565c. 8vo.

. Epistolarum medicinalium libri III. Zurich: Froschauer, 1577.

. Epistolarum liber quartus. Wittenberg: Simon Gronenberg, 1584

. Bibliotheca universalis und Appendix. Osnabrück: O. Zeller, 1966.

. Mithridate (Mithridates, 1555). Ed. Bernard Colombat and Manfred Peters. Geneva: Droz, 2009.

Gilmont, Jean-François, and Alexandre Vanautgaerden. Offrir un livre, les dédicaces à l'époque humaniste, special issue of Nugae Humanisticae 3 (2003).

Glardon, Philippe. L'histoire naturelle au XVIe siècle: Introduction étude et édition critique de La nature et diversité des poissons de Pierre Belon (1555). Geneva: Droz, 2011.

Grafton, Anthony. Joseph Scaliger: A Study in the History of Classical Scholarship. Vol. 1, Textual Criticism and Exegesis. Oxford: Clarendon Press, 1983.

. The Culture of Correction in Renaissance Europe. London: British Library, 2011.

Horace. Odes and Epodes. Trans. Niall Rudd. Cambridge: Harvard University Press, 2004.

Hoyoux, Jean. 'Les moyens d'existence d'Erasme." Bibliothèque d'Humanisme et Renaissance 5 (1944): 7-59.

Jardine, Lisa. Erasmus, Man of Letters: The Construction of Charisma in Print. Princeton: Princeton University Press, 1993.

Johnson, William A. Readers and Reading Culture in the High Roman Empire: A Study of Elite Communities. Oxford: Oxford University Press, 2010.

Kapp, Friedrich. Geschichte des Deutschen Buchhandels. Volume 1, Bis in das siebzehnte Jahrhundert. Leipzig: Börsenvereins der deutschen Buchhändler, 1886.

Knight, Jeffrey Todd. Bound to Read: Compilations, Collections, and the Making of Renaissance Literature. Philadelphia: University of Pennsylvania Press, 2013.

Kusukawa, Sachiko. Picturing the Book of Nature: Image, Text, and Argument in Sixteenth-Century Human Anatomy and Medical Botany. Chicago: University of Chicago Press, 2012.

Leonhardt, Jürgen. Latin: Story of a World Language. Trans. Kenneth Kronenberg. Cambridge: Belknap Press of Harvard University Press, 2013. 
Leu, Urs B. "Die Bedeutung Basels als Druckort im 16. Jahrhundert." In Basel als Zentrum des geistigen Austauschs in der frühen Reformation, ed. Christine Christ-von Wedel, Sven Grosse, and Berndt Hamm, 53-78. Tübingen: Mohr Siebeck, 2014a.

. "Moral Treatment of Immoral Texts from Classical Antiquity: Conrad Gessner's MartialEdition of 1544." In Following Zwingli: Applying the Past in Reformation Zurich, ed. Luca Baschera, Bruce Gordon, and Christian Moser, 197-208. Farnham: Ashgate, 2014b.

. Conrad Gessner (1516-1565), Universalgelehrter und Naturforscher der Renaissance. Zurich: Verlag Neue Zürcher Zeitung, 2016a.

. “Conrad Gessners Netzwerk.” In Facetten eines Universums (2016b), 66-74.

Leu, Urs, Raffael Keller, and Sandra Weidmann eds. The Private Library of Conrad Gessner. Leiden: Brill, 2008.

Martin, Henri-Jean. La naissance du livre moderne (XIVe-XVIIe siècles): Mise en page et mise en texte du livre français. Paris: Editions du cercle de la librarie, 2000.

McKitterick, David. Print, Manuscript and the Search for Order, 1450-1830. Cambridge: Cambridge University Press, 2003.

Müller, Clemens. "“Conrado Gesnero Philologo'-Gessners Beiträge zur klassischen Philologie.” In Facetten eines Universums (2016), 85-98.

Nelles, Paul. "Reading and Memory in the Universal Library: Conrad Gessner and the Renaissance Book." In "Ars Reminiscendi": Mind and Memory in Renaissance Culture, ed. Donald Beecher and Grant Williams, 147-69. Toronto: University of Toronto Press, 2009.

Nutton, Vivian. "Conrad Gessner and the English Naturalists." Medical History 29 (1985): 93-97. Nyffeler, Reto. "Conrad Gessner als Botaniker.” In Facetten eines Universums (2016), 163-73.

Pettegree, Andrew. The Book in the Renaissance. New Haven: Yale University Press, 2010.

Pinon, Laurent. "Portrait emblématique du parfait mécène: Comment Ulisse Aldrovandi remercie le cardinal Montalto." In Conflicting Duties: Science, Medicine and Religion in Rome, 1550-1750, ed. Maria Pia Donato and Jill Kraye, 59-79. London: Warburg Institute, 2009.

Propertius. The Complete Elegies of Sextus Propertius. Trans. Vincent Katz. Princeton: Princeton University Press, 2004.

Schottenloher, Karl. Die Widmungsvorrede im Buch des 16. Jahrhunderts. Münster: Aschendorffsche Verlagsbuchhandlung, 1953.

Sebastiani, Valentina. "The Impact of Erasmus of Rotterdam's New Testament on the European Market (1516-1527): Considerations Regarding the Production and the Distribution of a Publishing Success." In Basel 1516: Erasmus' Edition of the New Testament, ed. M. Wallraff, S. Seidel Menchi, and K. von Greyerz, 225-37. Tübingen: Mohr Siebeck Verlag, 2016.

Sergeev, Mikhail. "Avtobiografija i avtobibliografija Konrada Gessnera" (in Russian, Conrad Gessner's autobiography and autobibliography). Srednie veka (Studies on Medieval and Early Modern History) 76.1-2 (2015): 191-209.

Serrai, Alfredo. Conrad Gesner. Ed. Maria Conchetti. Rome: Bulzoni, 1990.

Shapiro, Aaron. "Renaissance Cryptophilology: Scholars, Poets, and the Pursuit of Lost Texts." PhD diss., Boston University, 2014.

Sherman, William H. "The Beginning of 'The End': Terminal Paratext and the Birth of Print Culture." In Renaissance Paratexts, ed. Helen Smith and Louise Wilson, 65-87. Cambridge: Cambridge University Press, 2011.

Vanautgaerden, Alexandre. Erasme typographe: Humanisme et imprimerie au début du XVIe siècle. Geneva: Droz; Brussels: Académie royale de Belgique, 2012. 
Wackernagel, Rudolf, ed. Rechnungsbuch der Froben und Episcopius, Buchdrucker und Buchhändler zu Basel, 1557-1564. Basel: Benno Schwabe, 1881.

Waquet, Françoise. "Acknowledgments: Instructions for Use.” Modern Intellectual History 2 (2005): 361-85.

Weber, Berchtold. "Die Wappen Conrad Gessners und seiner Verwandten." In Facetten eines Universums (2016), 211-17.

Wellisch, Hans. Conrad Gessner: A Bio-Bibliography. Zug: IDC, 1984.

Woudhuysen, Henry. Sir Philip Sidney and the Circulation of Manuscripts, 1558-1640. Oxford: Clarendon Press, 1996.

Zedelmaier, Helmut. Bibliotheca universalis und Bibliotheca selecta: Das Problem der Ordnung der gelehrten Wissens in der frühen Neuzeit. Cologne: Böhlau, 1992.

Warm thanks to Joe Connors for the invitation to give this lecture at the RSA Annual Meeting in Boston on 1 April 2016. I am grateful to Tony Grafton for his careful comments on a draft of my lecture and to members of the audience for their feedback at the time and since. Carlos Gilly, Urs Leu, Mikhail Sergeev, Richard Yeo, and Helmut Zedelmaier kindly read a draft of this article and made valuable comments; Laura Christoffels lent her software skills to the charts and annotated image. My thanks to all those involved in the production of this piece and, more generally, to the many scholars and students who have made it such a pleasure to work in this field.

${ }^{1}$ The activities marking the 500th anniversary of Gessner's birth included a conference and major exhibit in Zurich and a number of publications: Leu, 2016a; Facetten eines Universums; and a special issue of Gesnerus (2016).

${ }^{2}$ For one recent exception, see Gessner, 2009. For digitizations of Gessner's works see www.erara.ch and www.bsb-muenchen.de, but also Gallica and Google Books.

${ }^{3}$ In defining Gessner's corpus, I have relied on Wellisch, section A, 31-100. See the bibliography for a complete list of Gessner's works, ordered chronologically by year and within each year by the month specified in the dedication; for the specifics of these dates, see the appendix in Blair, 2016. In the tally for fig. 1, I counted only first editions (although some later editions involved substantial additions) and I omitted works published without Gessner's involvement (Elenchus [1551]; De stirpium epistolae [1557]) or when his contribution was minimal, as I judged from the 
fact that someone other than Gessner composed the dedication (Josias Simler, Epitome [1555]; Josua Maler, Dictionarium germanicolatinum [1561]; Henri Estienne, Dictionarium medicum [1564]; Jacques Houllier, Viaticum novum [1565]). I opted to attribute the Dictionarium graecolatinum to 1545, when Gessner was named on the title page and composed the dedication for the first time, although Gessner prepared contributions to this work as early as 1537 and complained that they were not properly included.

${ }^{4}$ On Gessner's philological activity, see Müller; Baldi.

${ }^{5}$ In addition, Gessner edited and translated the sententiae of the Greek monks Maximus and Antonius of Melissa (1546), the apology of Athenagoras (a church father of the second century, 1559) and the quaestiones of Cassius Iatrosophista (second-third century, 1562); he also translated texts by Porphyry and Proclus (1542), Michael of Ephesus (1541), Michael Psellos and Georgios Pachymeros (1542), and Tatian (1546).

${ }^{6}$ Gessner edited manuscripts by Antonius Telesius (1545a), David Kyber (1553b), Valerius Cordus (1561a, 1563a, 1565b), Jodocus Willich (1563c), and Ioannes Moibanus (1565a); he calls attention to this activity in Gessner, $1563 \mathrm{c}$, sig. * $3^{\mathrm{v}}$.

${ }^{7}$ See for example Eisenstein, 98, 109-11, on the use of print to gather information, by Gessner and others.

${ }^{8}$ Martin; McKitterick.

${ }^{9}$ Pettegree, 53-55.

${ }^{10}$ Leu, 2014a.

${ }^{11}$ Wellisch, 14. For the most complete discussion of Gessner's finances see Leu, 2016a, 94-96, 348 and, for a German translation of this Latin letter, see 348-53. John Foxe similarly reported working for Froben and Episcopius under financial duress; see Grafton, 2011, 67-68.

12 Wackernagel, 20 re Elias Philippinus (paid 15l $2 s 2 d$ "pro Galeni recognitione"); 39 ("Gessnero pro praefatione," $15 l$ from Froben) and 41 ("Gessnero d.d." $15 l$ from Episcopius).

${ }^{13}$ Gessner, 1562c. With one gulden worth two pounds, Leu, 2016a, 96, points out that this rate of pay per folio sheet was double what Froschauer paid Bullinger per sheet in 1535.

${ }^{14}$ Gessner, 1562c, sig. a+3v: "Quoniam typographis placuit me in eos praefari, quibus ego propter multa praeclara eorum in me beneficia, quamvis probe tenuitatis meae conscius, meam operam negare non sum ausus." All translations are my own unless otherwise noted.

${ }^{15}$ Letter of Simon Sulzer in Basel to Gessner, Staatsarchiv Graubünden in Chur, shelfmark D V/37 C 36.06.26. Many thanks to Urs Leu for this information and reference.

${ }^{16}$ Kapp, 1:319 (chapter 5); and Leu, 2016a, 348.

${ }^{17}$ Ibid., 194. Gessner received his raise in mid-September 1558 but Gessner's neighbors expressed concern about disruption due to the planned extension already in June 1558. I am grateful to Urs Leu for this information. On the more general development of spaces devoted to study in early modern Europe, see Algazi.

18 Nutton, 96. See the entry of 7 March 1561 in the 1561-62 Calendar of State Papers, http://www.british-history.ac.uk/cal-state-papers/foreign/vol4/pp1-16\#fnn1. A few months later William Cecil disbursed six pounds to Gessner. See http://www.british-history.ac.uk/cal-cecilpapers/vol1/pp257-263.

19 "I am freer now by the grace of God; and my work is not as bound to and constrained by the printers, as it was entirely until now": Gessner to Kenntman, 27 Feb 1559, in Gessner, 1584, fol. $\mathrm{B}^{\mathrm{v}}-\mathrm{C} 1^{\mathrm{r}}$; discussed in Leu, 2016a, 354.

${ }^{20}$ I discuss this in more detail in an article that will appear in Professors, Physicians and Practices in the History of Medicine: Essays in Honor of Nancy Siraisi, ed. Cynthia Klestinec and Gideon 
Manning. On the special financial challenges and strategies involved in publishing illustrated books, see Kusukawa, 48-61.

${ }^{21}$ Horace, 216-17: "Exegi monumentum aere perennius / regalique situ pyramidum altius / . . . Non omnis moriar multaque pars mei / uitabit Libitinam; usque ego postera / crescam laude recens." On publication in the ancient world, see Johnson.

22 On the formation and long reach of the canon of Latin language and literature, see Leonhardt.

23 See http://www.roger-pearse.com/weblog/2009/10/24/what-percentage-of-ancient-literaturesurvives-some-data/. Without venturing an overall survival rate, an earlier scholar estimated that we have surviving works for only 20 percent of the Latin authors we know existed, and those works represent only part of those authors' production, while there were of course other authors of whose existence there is no trace; see Bardon, 13.

24 "To understand this better, gentlemen of Venice, consider also the following. How much of their literature did the Greeks lose since, at the time of their misfortunes, the Latins became so neglectful of these matters? What I am about to say is perhaps strange, but it is perfectly true. If we count the poets, orators, philosophers, and to put it briefly, past writers of works read by earlier generations of interested students, if we count all these, we shall find that perhaps we do not even have one per cent of them available to us now": Bembo, 36-37. I am grateful to Aaron Shapiro for this reference; see Shapiro, 49-50.

${ }^{25}$ On the difficulties of estimating early print runs, see Dane. For evidence from a primary source, see Gerritsen.

26 Pettegree, 49-50.

27 Gessner, 1545b, title page: "Bibliotheca universalis, sive Catalogus omnium scriptorum locupletissimus, in tribus linguis, Latina, Graeca, et Hebraica: extantium et non extantium, veterum et recentiorum in hunc usque diem, doctorum et indoctorum, publicatorum et in Bibliothecis latentium." As entry into the studies of the Bibliotheca, see Zedelmaier; Nelles.

${ }^{28}$ Gessner, $1545 \mathrm{~b}$, sig [*6] ${ }^{\mathrm{r}}$ : "I rejoice and give thanks to God immortal that I finally came out of this labyrinth which ensnared me for about three years. ... Now I look with joy on my labors and it pleases me to remember them: just like those who have come down a very high and steep mountain admire that they have returned when they are below again and congratulate themselves on overcoming a difficult path."

${ }^{29}$ Ibid., sig * $2^{\text {r: }}$ "Ubi nunc sunt septingenta milia librorum bibliothecae Ptolemaei Philadelphi, et Tyrannionis tria milia. A. Gellius scribit Alexandriae milia voluminum septingenta per milites combusta esse." In his copy of the Bibliotheca Gessner corrected "tria" to "triginta" in a manuscript note because, indeed, the Suda reported that the Greek grammarian Tyrannion had collected 30,000 books, not 3,000. See the copy at the Zurich Zentralbibliothek Dr M 3, which has been digitized on e-rara.

${ }^{30}$ Gessner, 1545b, sig. *2v: "Quid vero nunc ex omnibus illis tam gloriosis bibliothecis praeter inanem famam reliqui est? .. . Quandoquidem igitur tot et tam pretiosi in omni philosophia libri paulatim amissi sunt, partim flammis aut bellorum tumultibus consumpti partim ipsa vetustate tineis ac situ corrupti, plurimi vero dissipati negligentia et odio in literas barbarorum."

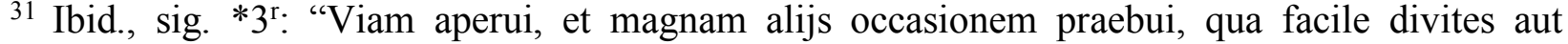
principes viri Bibliothecas instituant, libris ad posteritatem transmittendis necessarias."

32 Ibid., sig * $3^{\mathrm{r}-\mathrm{v}}$ : "Et nimium exquisita forte aut curiosa diligentia, quaecunque inter legendum citata nomina occurrebant, statim annotavi: . . . et illos, a quibus nihil editum extat, nisi praefationes quaedam, aut etiam una solum, vel epistola una." 
33 On early modern interest in nuda nomina (bare names) (mostly after Gessner's time), see Clark, 119-61.

${ }^{34}$ For example, Gessner wrote to Caspar von Niedbruck to inquire on behalf of the printer Isengrin whether he knew of any good-quality manuscripts of unpublished ancient texts; Leu, 2016a, 133. Nor was Gessner alone in his interest in fragments. In 1564 Henri Estienne published a collection of fragments from ancient Latin poets drawing on the work of Robert Estienne in the 1550s; see Grafton, 1983, 93.

${ }^{35}$ Gessner, 1551b, sig. a[4] $]^{\mathrm{v}}-\mathrm{b} 1^{\mathrm{r}}$ : "Suppeditabit hodie autores omnis generis ars typographica, ad literas posteris conservandas nostrae tempestatis hominibus divinitus concessa, qua tantum una die ab homine etiam literarum imperito exprimitur, quantum vix toto anno a compluribus penna licet properantissima exarari esset possibile."

${ }^{36}$ Ibid., sig *3. "Quamvis enim ars typographicae librorum conservationi nata videatur, ut plurimum tamen nostri temporis hominum nugae et inutilia scripta, vestustis et melioribus neglectis in lucem eduntur: quare pro manuscriptis saltem libris opus est Bibliothecis."

${ }^{37}$ See Erasmus, Adages 2.1.1 ("festina lente") in Erasmus, 7-28, especially lines 280-376.

${ }^{38}$ Beck von Beckenstein was the only person, along with Johann Jakob Fugger, to receive three dedications from Gessner: in 1545a, 1545b, and the foldout table to $1555 \mathrm{~h}$. In addition Gessner thanked him in $1548 \mathrm{~b}$, sig. $* 2^{\mathrm{r}}$. On his ownership of Greek manuscripts, see Serrai, 90.

${ }^{39}$ Gessner, 1556c, sig. $\alpha 2^{\text {r. }}$ " Redeunti igitur ad te Aeliano tuo, iam integro, emendato, bilingui, publico, facilem ac benignum te praebe, et in bibliothecam tuam veluti hospitij iure admitte."

${ }^{40}$ Gessner, 1565a, sig. [ $\left.\alpha 7\right]^{\mathrm{r}}$ : "Et hoc volumen, si placet, Bibliothecae vestrae (urbis ornamento per vos inchoato, et in perpetuum augendo) addite."

${ }^{41}$ Andrew Pettegree has estimated at 1 percent the overall survival rate of early printed books, taking into account the many editions of small-format and cheap books that likely do not survive at all: Pettegree, 334. The survival rate is higher for large-format and more expensive booksremarkably, for example, the Gutenberg Bible survives in forty-nine copies out of the 150 that were printed. But the central point of Pettegree's observation is that the considerable number of extant early printed books results not from the survival rate itself, but from the large number of copies printed.

${ }^{42}$ See the list of correspondents in Leu, 2016a, 389-406, and a graph of their locations, in Leu, 2016b, 66-67. Gessner's liber amicorum, available online through the National Library of Medicine, contains entries from 227 different visitors, as studied in Durling.

${ }^{43}$ Gessner, 1577 and 1584, and Zentralbibliothek Zurich, MS C50a, available on e-manuscripta. Studies include Delisle, 2006 and 2008.

${ }^{44}$ For a survey of Gessner's paratexts, see Blair, 2016.

45 "I especially ask, if there is another language in the British kingdom (indeed I hear that the islands of Ireland and of Man have their own) that you send us at an opportune time some specimen of them, especially from the Lord's Prayer": Gessner, 1555h, sig. A2 .

${ }^{46}$ Ibid., 78": "De omnibus enim linguis scribere sum ausus, non sane quod argumento me satisfacturum sperarem . . . sed ut excitarem alios, qui de singulis pluribusve sive ipsi lucubrationibus propriis, quod mallem: sive ad me nostra aliquando augendi aut emendandi gratia perscriberent."

${ }^{47}$ Zentralbibliothek Zurich MS 204a-c; for some discussion, see Blair, 2010, 216-24. For his correspondence with Caspar Bauhin about cutting up letters, see also Leu, 2016a, 116-18.

48 See Waquet.

49 For an entry into studies of dedications, see Bloemendal; Gilmont and Vanautgaerden; 
Schottenloher.

${ }^{50}$ Gessner, 1545a, sig. a $4^{\mathrm{r}-\mathrm{v}}$ : "Itaque eruditi alicuius viri scripta tibi nuncupatim dedicare volui, quae quidem huiusmodi forent, ut perpetua viderentur futura: quod ego de meis sperare nec possum, nec debeo."

${ }^{51}$ Gessner, $1549 \mathrm{c}$, sig. $++3^{\mathrm{r}-\mathrm{v}}$ : "Non iniucundam eius in nomina vestra inscriptionem vobis futuram existimavi."

${ }^{52}$ Gessner 1559c, sig. A2 ${ }^{\mathrm{r}}$ (internal dedication to Joannes Echtius): "Accepi tandem piscium Oceani Germanici quas ad me dedisti Eicones tam diu desideratas ornatissime Echti: pro quibus ne verbis tantum gratias tibi agere, re ipsa etiam qualecunque gratitudinis specimen exhibere volui."

${ }^{53}$ Gessner $1563 \mathrm{c}$, sig. $* 6^{\mathrm{r}}, * 7^{\mathrm{r}}$.

${ }^{54}$ Gessner, 1560c, 128: "Poterit [praestare] et Io. Caius, medicus ille et philosophus summus: a quo imagines tum Avium tum aliarum animantium, una cum descriptionibus accurate ab eo perscriptis, hactenus permultas accepi."

${ }^{55}$ Ibid.: "Quod si authoritate tua effeceris, ut viri aliqui docti apud vos, illarum avium quae in Anglia reperiuntur ultra eas quas hic exhibui, effigies mihi communicent, librum hunc alias ijs ipsis iconibus, et alijs forte (si quas aliunde interim nanciscar) Domino Opt. Max. vitam largiente, augendum curabo."

${ }^{56}$ Gessner, 1551a, sig. [a6] $]^{\mathrm{v}}$; discussed in Blair, 2016, 77-78.

${ }^{57}$ Kusukawa, 59.

${ }^{58}$ Gessner, 1553c, 59: "Statueramus Quadrupedes omnes, non temere, sed certis singulas ordinibus et inter suas congeneres, enumerare. Impedivit institutum hoc sculptoris tarditas: quare hic reliquas adijcimus, quas ut facile unusquisque ad suum ordinem redigat, ad quem referendae sint quaeque adscribemus."

${ }^{59}$ See Caius; on his relationship with Gessner, see Anthony Grafton's lecture at the Gessner conference in June 2016 entitled "John Caius and Conrad Gessner," which will be published in a volume from the conference, edited by Urs Leu.

${ }^{60}$ Gessner, 1553c, sig. [H5] : "Mittent et amici quidam fortassis aut etiam ignoti nobis, sed rerum naturae studiosi homines, etiam alias effigies quas nobis deesse animadverterint. Eas quoque nos prima quaque commoditate separatim aedemus ut hisce adiungi possint: ut et reliquas de caeteris animantium generibus figuras."

${ }^{61}$ Compare Gessner, 1553c, sig. [H5] , and "Appendix historiae quadrupedum viviparorum," in Gessner, 1554, 4 (biso Scoticus), 10 (musmonis), 16 (simia tartaris); but the images of the rana rubeta and the testudo terrestris are not supplied in 1554.

${ }^{62}$ Gessner, 1555b, sig. [a6] : "Rogo itaque doctos omnes in remotissimis regionibus, qui in hos libros inciderint, primum ut aequos ac benignos censores se nobis exhibeant, deinde si quid ad eos emendandos, augendos, iconibus et descriptionibus novis, aut quoquo modo illustrandos conferre possunt, id candide, liberaliter matureque ut faciant."

${ }^{63}$ Ibid.: "Ego quoque eadem via ad viros doctos et liberales, quorum nomina et voluntatem cognovero, tum scribendo, tum si quid desiderarint mittendo gratum me declarare potero."

64 "You live (if I am not mistaken) in a remote part in the North of Germany, in the honorable town of Munda situated on the noble river Weser, at [the court of] the most illustrious Eric of Braunschweig": Gessner, 1556b, 94. Today's Hannoversche Münden is indeed where the river Weser (Visurgis) is formed.

${ }^{65}$ Gessner, 1556b, 94-95: "Thomas Erastus Helvetius, civis meus, . . . suis nuper ad me literis eruditionem simul et humanitatem tuam, clarissime Mythobi, splendide praedicavit. Et icones 
aliquot animantium raras, Balthici praesertim maris aquatilium, te possidere adiecit, quas mihi communicaturum te sis pollicitus, si qua commoditas tanto locorum intervallo mittendi daretur. . . - [T] e ante omnes et patronum illius optimum et censorem doctissimum, deligendum mihi constitui. . . . Id autem ut perficias, et simul quotquot habes pictas aut delineatas, imprimis Aquatilium, effigies, earum me participem facere digneris. . . . Vidi ante annos aliquot egregias lucubrationes tuas, Stereometriam et Annuli Astronomici compositionem, magno ab eruditis hominibus applausu acceptas." Burkhard Mithoff was the author of a few German works, including a practica, and of Stereometria, ars oeconomica (Frankfurt: Christoph Egenolph, 1544) and Annuli cum sphaerici tum mathematici usus et structura (Marburg: Eucharius Cervicornus, 1536), which Gessner mentions here.

${ }^{66}$ Glardon, 167; it is striking that "bare names" were a challenge common to philology as well as natural history.

${ }^{67}$ Gessner, 1558, sig. [b5] $]^{\mathrm{r}}$ : "Clarorum virorum, deque nobis in hoc opere bene meritorum, qui nostros conatus benigne iuverunt, plerique vel ab initijs praecedentium librorum Historiae animalium, vel in hoc ipso opere suis locis passim nominantur."

${ }^{68}$ For a list of dedications, see Blair, 2016.

69 On Erasmus's remarkable publishing savvy, see Jardine; see also Vanautgarden, who enumerates the 221 works in his appendix. On Erasmus's dedications, see Hoyoux, 43-49.

70 Calendar of State Papers, 7 March 1561.

${ }^{71}$ Reproduced in Leu, 2016a, 248; see Weber.

72 See Pinon.

${ }^{73}$ Gessner, 1561a, sig Bbij": "Sunt et Succini orientalis globuli duo, carissima munora [for munera] tua, candore et perspicuitate crystalli: Quod tantae authoritatis est, sicuti scribis, ut reginis Portugalliae dotem impleat, et pro suavissimo preciosoque suffitu Ulyssibonae uratur: cuius in literis nulla hactenus, quod sciam, memoria fuit."

${ }^{74}$ Gessner, 1551a, sig. $\gamma 1^{\text {r. }}$ " CCatalogus doctorum virorum, qui ut opus hoc nostrum et rempub. literariam illustrarent, vel aliunde imagines animalium, aut nomina et descriptiones miserunt: vel praesentes communicarunt."

${ }^{75}$ Ibid., sig. $\gamma^{\mathrm{r}-\mathrm{v}}$; Gessner, 1555b, sig. $6^{\mathrm{r}}$; Gessner, 1558, sig. b4 ${ }^{\mathrm{r}}$.

76 Others thanked twice, in 1551 and 1558, are Achilles Gasser, Cornelius Sittard, Georgius Fabricius, William Turner, Hieronymus Froben, Ioannes Falconer, Ioannes Kenntman, and Ioannes Ribittus. On Massarius, see Leu, 2016a, 122.

${ }^{77}$ Gessner, 1551a, sig [a6] $]^{\mathrm{r}}$ : "Typographus ad lectorem: 'Et, ut hoc obiter dicam, dedissemus forte etiam primi Tomi Bibliothecae ex officina nostra superioribus annis publicatae Epitomen, nisi iam a nescio quo inscijs nobis id fieri audiremus." It is less clear whether Gessner was displeased. In any case in 1555 Gessner explained that "the printer was pleased to reprint that same epitome compiled by Lycosthenes (the copies of which we had heard were all sold out) augmented with what we collected." Gessner, 1555d, sig [*5] ${ }^{\mathrm{r}}$. I am grateful to Carlos Gilly for this observation.

78 Gessner, 1555b, sig. [A5]v: "Et ego nuper amico meo Hieronymo Massario Italo medico excellenti author fui, ut optimos vetustissimosque rei medicae authores in Pandectas redigeret, quod opus iam propemodum ab eo confectum et brevi Basileae excudendum spero."

${ }^{79}$ Sebastiani, 235nn48-50.

${ }^{80}$ Gessner, 1553c, sig. [H5]": "Ipsius quidem Historiae et descriptionis animalium reliquorum post quadrupedes Volumen Latinum iam sub praelo est: et Tomus primus de quadrupedibus in Germanicum sermonem translatus: qui etiam Gallice propediem excudetur." See Thierbuch, trans. 
Conrad Forer (Zurich: Froschauer, 1563); and Geoffroi Linocier, Histoire des plantes (Paris: Charles Macé, 1584).

${ }^{81}$ Gessner, 1545b, $180^{\mathrm{v}}-185^{\mathrm{r}}$; Gessner, 1562e. The entries for him in Gessner, $1555 \mathrm{~d}$, $38^{\mathrm{r}-\mathrm{v}}$, and $1555 \mathrm{c}, 24^{\mathrm{v}}-25^{\mathrm{r}}$, list only his published works. In the Bibliotheca instituta of 1574 and 1583 the entry for Gessner comprised the text of the De libris a se editis with a corollarium listing works published after 1562 and many manuscripts that Gessner left at his death. On the prominence of autobiography in his work, see Sergeev.

82 Turner also appears on two lists of "those who helped," in 1551 and 1558. Turner had visited Gessner in 1540; see Leu, 2016a, 63, who cites Gessner, 1555f, 34.

83 "If some kind Maecenas would come forward, under whose auspices the project would be carried out, the whole project would be accomplished more perfectly": Gessner, 1545, 182v. "Others who have written recently on fish in France and Italy had popes or cardinals as their wealthy Maecenas. Since I lack so far in this project a patron and Maecenas, I am more worthy of pardon if in any place I do not satisfy expectation": Gessner, 1558, sig. [a5] $]^{\mathrm{v}}$.

${ }^{84}$ See Gessner, 1545b, 182 $-183^{\mathrm{r}}$; Gessner, 1562e, sig. [B7] ${ }^{\mathrm{r}}$, para. 5. On Gessner's reliance on images in a manuscript of Oppian, see Leu, 2016a, 208, 423.

85 "And when about three years ago as a guest of Oporinus I found this book in his very abundant library, and attracted by the novelty of the title, when I asked if he could give it to me to read, I obtained it easily; just so did my cousin obtain recently from him permission to print it on his press": Gessner, $1563 \mathrm{c}$, sig. *2r.

86 "When these days my cousin Andreas Gessner was printing Ioannis Leo's Africa and asked if I could add something new of mine, since I did not have leisure for greater things, I suddenly translated into Latin the Navigatio of Hanno and added some comments written altogether too rapidly, in the work of just a short day": Gessner, 1559b, sig. $\alpha 2^{r}$. "My cousin the printer coincidentally had this in press . . . and asked me if I could add something new of my own": Gessner, 1563b, 721. "Now finally, at the request of my cousin the printer to supply something for his idle press, I put together this little book from my papers": Gessner, 1562b, sig. A2v".

87 "When I published this book prematurely for the sake of my cousin Andreas Gessner, then a new printer, I did not want to add my name": Gessner, 1562e, sig. A8v-B1 ${ }^{\mathrm{r}}$, para. 37.

${ }^{88}$ On Gessner's advice to cut and paste from printed books, notably in order to index a work, see Gessner, 1548b, 19-20r as discussed in Blair, 2010, 96-97.

${ }^{89}$ The Zentralbibliothek Zurich holds Gessner's own annotated copies of 1544b, 1544c, 1545b, $1546 \mathrm{a}, 1546 \mathrm{~b}, 1556 \mathrm{c}, 1560 \mathrm{a}-\mathrm{c}, 1563 \mathrm{c}$, and 1565a. For a full bibliography of works annotated by Gessner, see Leu, Keller, and Weidmann.

90 "Quae manus obscenas depinxit prima tabellas, / Et posuit casta turpia visa domo, / Illa puellarum ingenuos corrupit ocellos, / Nequitiaeque suae nolui esse rudes.” The eight lines Gessner adds are from Propertius, Elegies 2.6 (lines 27-34); translation from Propertius, 103. The selection is marked up with instructions to the printer: "pone post lin. 2 ante elegiam ad Cynthiam, quae incipit, Gavisa es," that is, "to position [these lines] after line 2 before the elegy to Cynthia which starts 'Gavisa es." Indeed Elegy 2.7 begins "Gavisa es certe sublatam, Cynthia, legem" ("Cynthia delights, certainly, that the law has been lifted”): see Propertius, 105. These instructions might be remnants of an earlier use of the text, e.g., in proofs for publication. It is not clear what if anything the annotations mean here, but the printed passage is clearly relevant to Gessner's point about the need for expurgation. On Gessner's arguments in this edition, see Leu, 2014b.

${ }^{91}$ Gessner was no doubt referring to Iani Damasceni . . . Therapeuticae methodi hoc est curandi artis libri VII (Basel: Henricpetri, 1543). See Gessner, 1545b, fol. 454 ${ }^{\mathrm{v}}$, in Gessner's own copy at the 
Zentralbibliothek Zurich, shelfmark Dr M 3, as digitized on e-rara, and compare with that page in Gessner, 1966. For a reproduction of fol. $455^{\mathrm{r}}$ in Gessner's copy, which features a further printed paragraph that was substituted for the page printed originally, see Blair, 2010, 224.

92 Gessner, 1545b, sig. * $5^{\text {r: }}$ "Novi et hodie quosdam (qui inter bonos et doctos homines numerari cupiunt) a quibus librorum tituli ad imponendum emptoribus dolo malo immutantur, et opera tota interpolantur, ut pro novis obtrudi possint: quorum nominibus quanquam in praesentia abstinuerim, $\mathrm{ab}$ amicis persuasus, si tamen ita pergant, et Deus mihi concesserit, efficiam ut eos sui facinoris poeniteat."

${ }_{93}$ Woudhuysen 15, referring to Samuel Daniel and Michael Drayton.

94 On Parker, see Knight, 47-51, and the paper delivered by Madeline McMahon on "Parker and Ecclesiastical History" at the conference "Matthew Parker: Archbishop, Scholar and Collector," held at CRASSH and Corpus Christi College, Cambridge, in March 2016, which will appear in a volume in due course. See also Anthony Grafton's Sandars Lecture at Cambridge University delivered on 27 January 2016, available here: http://www.lib.cam.ac.uk/about-library/prizes-andfellowships/sandars-readership-bibliography/sandars-lectures-2016.

95 On Cordus, see Dannenfeldt, 229-35. On Gessner's discontent with Rihel, see Leu, $2016 \mathrm{a}, 257$. ${ }^{96}$ Nyffeler, 168-71.

${ }^{97}$ Leu, 2016a, 261. On "finis," see Sherman.

${ }^{98}$ Gessner, 1561a, sig. Vu: "Cum liber meus De hortis Germaniae ad finem operum Val. Cordi Argentinae imprimendus, ad manum non esset: nec revocari, typographo ad operis finem festinante, ut suis quaeque locis alphabeticae seriei insererentur, posset." 